\title{
COVID-19 Salgını Sebebiyle Uygulanan Sokağa Çıkma Kısıtlamalarının 1982 Anayasası'na Uygunluğu
}

\author{
Volkan Aslan* (1)
}

Öz

Türkiye'de COVID-19 salgınıyla mücadele kapsamında iki ayı aşkın süredir sokağa çıkma kısıtlamaları uygulanmaktadır. İçişleri Bakanlığı tarafindan çıkarılan genelgelerle öngörülen bu kısıtlamaların dayanağı olarak ì İdaresi Kanunu ile Umumi Hıfzısıhha Kanunu gösterilmektedir. Ancak söz konusu kanunlarda yer alan düzenlemelerin sokağa çıkma kısıtlamalarına dayanak olması mümkün değildir.

Resmi olarak ilân edilmiş bir olağanüstü hâl söz konusu olmadığından olağan dönemde temel hak ve hürriyetleri sınırlandıran önlemlerin alınabilmesi, 1982 Anayasası'nın 13. maddesinde sayılan koşullara uyulmasını gerektirmektedir. Salgın sebebiyle uygulanan sokağa çıkma kısıtlamalarının 1982 Anayasası'nın ilgili maddelerinde belirtilen sebeplere bağlı olduğu ileri sürülebilirse de 13. maddenin aradığı diğer bir koşul olan kanunilik ilkesinin gereklerine uyulmadığı görülmektedir. Nitekim temel hak ve hürriyetleri sınırlandırırken uyulması gereken kanunilik ilkesi gereğince, kanunların sınırlama ile ilgili belirli hususları açıkça düzenlemesi gerekmektedir. Sokağa çıkma kısıtlamalarına dayanak olarak gösterilen kanunlarda ise sokağa çıkma kısıtlamaları açıkça zikredilmediği gibi kısıtlamaların kapsamı, biçimi, süresi ve uygulanacak güvenceler gibi temel konulara da yer verilmediği görülmektedir.

\section{Anahtar Kelimeler}

COVID-19, Salgın hastalık, Sokağa çıkma kısıtlamaları, Olağanüstü hâl, ì İdaresi Kanunu, Umumi hıfzısıhha kanunu, Olağanüstü hal Kanunu

\section{Constitutionality of COVID-19 Related Curfews in Turkey}

\section{Abstract}

General curfews are imposed in Turkey due to the COVID-19 pandemic since early March. The Ministry of Interior grounded its competence on the Law on Provincial Administration and Law on General Protection of Public Health and issued directives for this purpose. However, imposing curfews with ministerial directions seems quite problematic based on these laws.

Restricting fundamental rights and freedom requires compliance with the conditions listed in Article 13 of the Turkish Constitution as the state of emergency is not officially declared. Basic rights and freedom could be restricted for the reasons specified in the Constitution according to this article. In addition, restrictions should be based on laws accepted by the Grand National Assembly of Turkey. These laws must specify the conditions in an obvious and predictable manner.

These restrictions do not fulfill the requirements of legality, although it can be claimed that curfews are related to the reasons stated in relevant articles of the 1982 Constitution. The laws do not refer to curfews or similar restrictions explicitly, which are cited as the basis for curfews. They also do not contain guarantees such as scope, form, duration, or

* Sorumlu Yazar: Volkan Aslan (Dr. Öğr. Üyesi) İstanbul Üniversitesi, Hukuk Fakültesi, Anayasa Hukuku Ana Bilim Dalı, İstanbul, Türkiye. E-posta: volkan.aslan@istanbul.edu.tr, ORCID: 0000-0003-1136-7556

Atıf: Aslan V, “COVID-19 Salgını Sebebiyle Uygulanan Sokağa Çıkma Kısıtlamalarının 1982 Anayasası'na Uygunluğu” (2020) 78(2) İstanbul Hukuk Mecmuası 809. https://doi.org/10.26650/mecmua.2020.78.2.0018 
safeguards to be applied during the restrictions. It could be concluded that general curfews imposed in Turkey due to the COVID-19 pandemic are unconstitutional under these conditions.

\section{Keywords}

COVID-19, Pandemic, curfew, State of emergency, Law on provincial administration in Turkey, Law on general protection of public health in Turkey, Law on state of emergency in Turkey

\section{Extended Summary}

The Turkish Government issued several acts with the intent of preventing the spread of the virus after announcing the first confirmed case of COVID-19 on March 11, 2020. Moreover, a valid ground emerged for the declaration of a state of emergency: Article 119 of the Turkish Constitution empowers the President of the Republic to declare a state of emergency in the event of the serious deterioration of public order caused by the outbreak of dangerous pandemics. However, the state of emergency was not declared and the government chose to use its ordinary powers instead. Therefore, the Interior Ministry issued directives banning people over the age of 65, people with chronic diseases, and people under the age of 20 from leaving their homes. General curfews were also imposed in big cities on weekends more than ten times with these directives. Serious questions have been raised regarding the constitutionality of the restrictions as these directives lack explicit statutory authorization and the state of emergency has not been declared.

Basic rights and freedom could be restricted for the reasons specified in Article 13 of the Turkish Constitution. Moreover, the restrictions should be based on laws accepted by the Grand National Assembly of Turkey. These laws have to be certain and accessible. Therefore, "laws accepted by the Grand National Assembly of Turkey" should be interpreted in a nuanced way: Laws have to contain content-wise qualities such as clarity, obviousness, and predictability. Only under these conditions, the requirements of legality could be met.

The recent curfews in Turkey are grounded on Article 11/C of the Law on Provincial Administration and Article 27 and 72 of the Law on General Protection of Public Health. According to Article 11/C of the Law on Provincial Administration, Duties of the provincial governors include exercising preventive police patrols, providing and preserving peace, security, personal inviolability, freedom of action and public welfare within the cities. To ensure these duties, the governor must take necessary measures. In cases where there is a risk of deterioration of public order and safety in such a way that ordinary life is threatened, the governor may restrict entries and exits to the city for persons who are suspected of having the potential to disrupt public order or public security, regulate or restrict roaming or gathering of people and navigation of vehicles in certain places or hours, prohibit bearing or transportation 
of all types of weapons and bullets including the registered ones. These measures cannot exceed fifteen days.

Article 27 of the Law on General Protection of Public Health regulates general duties of public hygiene assemblies. Moreover, Article 72 of the law regulates measures mostly applicable to infected citizens, infected animals, and danger zones. Restriction of rights of the "noninfected cases" is not regulated in both the articles. As it is seen, neither the Law on Provincial Administration nor the Law on General Protection of Public Health empowers the government to impose general limitations on basic rights. General curfews cannot be imposed based on these laws under these circumstances.

It could be said that lawful curfews could be imposed only after declaring an official state of emergency considering the current legislation in Turkey. However, the government does not want to declare an official state of emergency and prefer to manage the crisis with ordinary legislation. Hence, laws restricting basic rights are interpreted widely, and unusual competences are justified under the cover of fighting against the COVID-19 pandemic. Therefore, there is an urgent need to adopt new and detailed laws to be applied during pandemics. Otherwise, the only way to legalize curfews could be declaring a state of emergency. It could be concluded that general curfews imposed in Turkey due to the COVID-19 pandemic are unconstitutional under these conditions (also see Volkan Aslan, "Turkey's Struggle Against COVID-19 and the New Reign-by-Administrative-Act" [IACL-IADC Blog 2020]<https://blogiacl-aidc.org/2020-posts/2020/7/16/turkeys-struggle-against-covid-19-and-the-newreign-by-administrative-act>). 


\title{
COVID-19 Salgını Sebebiyle Uygulanan Sokağa Çıkma Kısıtlamalarının 1982 Anayasası'na Uygunluğu
}

\begin{abstract}
"Ünlü bir Fransız avukatı olan Tolemon şunu anlatır: Genç bir avukattım. Karşı tarafin avukatı, İ̧işleri Bakanı'nın yeğeni idi. Mahkemeye bir genelge ibraz etti. Davasını birkaç gün evvel İçişleri Bakanlığı'nın yayınladiğı bu genelge ile ispata çalışıyordu. Ben savunmamı yaparken mütemadiyen sözümü keserek genelgeyi hatırlatıyordu. Hakim kizdl. "Sizin genelgeniz ne kanun ne de içtihattır." dedi. Biraz evvel ibraz edilen genelgeyi sepete attl ve bana dönerek "Devam ediniz." dedi. Sonunda davayı kazandım."'
\end{abstract}

\section{Giriş}

Türkiye'de ilk COVID-19 vakasının teşhis edildiği 11 Mart 2020 tarihinden bu yana çoğunluğu İçişleri Bakanlığı tarafından çıkarılan genelgelerle olmak üzere, temel hak ve özgürlüklerle ilgili birçok sınırlama getirilmiş; getirilen sınırlamalara aykırı davrananlarla ilgili adli ve idari işlemler yapılmıştır. Bu çerçevede barların, gece kulüplerinin, tiyatroların, sinemaların, restoranların, kafelerin, hamamların, spor salonlarının vb. kapatılması; ulusal ve uluslararası düzeydeki bilimsel, kültürel, sanatsal ve benzeri toplantıların ertelenmesi; 65 yaş üzeri ve 20 yaş altı olanlar ile kronik rahatsızlığı bulunanlara sokağa çıkma kısıtlamaları getirilmesi; hafta sonları genel sokağa çıkma kısıtlamalarının uygulanması; şehirler arası yolculukların kaldırılması gibi sınırlamalar söz konusu olmuştur. Çoğunluğu İç İşleri Bakanlığının çıkardığı genelgelerle uygulanan sınırlamaların kanuni dayanağı olarak İl İdaresi Kanunu'nun 11. maddesinin C fikrası ile Umumi Hifzısıhha Kanunu'nun 27. ve 72. maddeleri gösterilmiştir. Çalışmada söz konusu düzenlemelere dayanılarak getirilen sokağa çıkma kısıtlamalarının 1982 Anayasası'na uygunluğu değerlendirilecektir. $\mathrm{Bu}$ amaçla ilk olarak temel hak ve özgürlüklerin sınırlandırılması koşullarından bahsedilecek, ardından sokağa çıkma kısıtlamalarının bu koşullara uygunluğu incelenecektir.

\section{1982 Anayasası Uyarınca Temel Hak ve Özgürlüklerin Sınırlandırılması}

1982 Anayasası uyarınca temel hak ve özgürlüklerin sınırlandırılma koşulları içinde bulunulan dönemin özelliklerine göre değişmektedir. Nitekim Anayasa'nın 13. maddesinde genel olarak temel hak ve özgürlüklerin sinırlandırılması konusu düzenlenmekte; "temel hak ve hürriyetlerin kullanılmasının durdurulması" başlıklı 15. maddede ise savaş, seferberlik ve olağanüstü hallerde, temel hak ve özgürlüklerin kullanılmasının kısmen veya tamamen durdurulabileceği veya bunlar için Anayasa'da öngörülen güvencelere aykırı tedbirler alınabileceği belirtilmektedir. Dolayısıyla bir temel hak ve özgürlüğe müdahale edildiğinde öncelikle içinde bulunulan dönem tespit edilmeli ve hangi güvence rejiminin uygulanacağı belirlenmelidir. Ancak 15.

Faruk Erem, Bir Ceza Avukatının Anıları, (14. Bası, Lykeion 2020) 44 
maddede sayılan olağanüstü durumlarda dahi müdahalenin ilk olarak 13. maddede belirtilen koşullara uygun olup olmadığı incelenmeli; 13. madde çerçevesinde müdahalenin Anayasa'ya uygun olmadığı belirlenirse 15. madde çerçevesinde bir inceleme yapılmalıdır. Anayasa Mahkemesi de hem olağanüstü hâlle bağlantılı bireysel başvurular hem de kanunlaşan olağanüstü hâl kararnamelerinin anayasallık incelemesi bakımından 15. madde çerçevesinde öncelikle 1982 Anayasası'nın 13. maddesine uygunluk incelemesi yapmakta, uygunluk olmaması halinde 15. maddedeki ölçütleri devreye sokmaktadır. Mahkemenin belirttiği üzere, “(...) olağanüstü yönetim usullerinin uygulandiğl dönemde temel hak ve özgürlüklere müdahale teşkil eden bir tedbirle ilgili olarak yapılan bireysel başvurularda Anayasa'nın 15. maddesi kapsamında yapılacak ilk inceleme, bu tedbirin olağan dönemin ölçütlerine göre Anayasa'da öngörülen güvencelere aykırı olup olmadığını tespit etmeye yönelik olacaktır. Bu durum Anayasa'nın 15. maddesinde yer alan “. ... Anayasada öngörülen güvencelere aykırı tedbirler alınabilir. "ibaresinin de bir gereğidir." 2 Norm denetiminde de Mahkeme benzer şekilde hareket etmektedir. ${ }^{3}$

Şimdi sıra, COVID-19 sebebiyle getirilen sokağa çıkma kısıtlamalarının hangi güvence rejiminin ölçütleri uyarınca incelenmesi gerektiğini tespite gelmektedir. Söz konusu virüsün ülkemizde yayılması sebebiyle Mart ayından bu yana olağanüstü koşullar altında yaşadığımız su götürmez bir gerçek olsa da 1982 Anayasası'nın öngördüğü şekilde ilân edilmiş bir olağanüstü hâl mevcut değildir. Her ne kadar 15. maddede ifade edilen, "olağanüstü hallerden birisinin" salgın hastalık sebebiyle mevcut olduğu düşünülebilirse de 15. maddenin uygulanabilmesi için Anayasa’nın 119. maddesi uyarınca resmi olarak ilân edilmiş bir olağanüstü hâlin varlığı zorunludur. $\mathrm{Bu}$ durumda, COVID-19 sebebiyle getirilen sokağa çıkma kısıtlamalarının 1982 Anayasası'nın 13. maddesinde belirtilen koşullara uygunluğunun incelenmesi gerekmektedir.

1982 Anayasası'nın 13. maddesi uyarınca “Temel hak ve hürriyetler, özlerine dokunulmaksızın yalnızca Anayasanın ilgili maddelerinde belirtilen sebeplere bağlı olarak ve ancak kanunla sinırlanabilir. Bu sınırlamalar, Anayasanın sözüne ve ruhuna, demokratik toplum düzeninin ve lâik Cumhuriyetin gereklerine ve ölçülülük ilkesine aykırı olamaz." Görüldüğü üzere maddede 7 koşul öngörülmektedir. Bu çerçevede sinırlama yapılırken,

\footnotetext{
Anayasa Mahkemesi, Bireysel Başvuru, 2016/22169, 20.06.2017, § 193.

"Olağanüstü yönetim usulünün uygulandığı dönemde temel hak ve özgürlüklere yönelik sinırlamayı konu edinen kurallara ilişkin olarak Anayasa'nın 15. maddesinin uygulanması gerektiği durumlarda da bu maddeye ilişkin inceleme yapılmadan önce sınırlamaya konu hakkın düzenlendiği Anayasa maddesi başta olmak üzere Anayasa'nın ilgili hükümleri ve olağan dönemde hak ve özgürlükleri sinırlama ve güvence rejimini düzenleyen Anayasa'nın 13. maddesi kapsamında bir inceleme yapılmalıdır. Zira devletin veya toplumun varlı̆̆ına ya da kamu düzenine yönelik ciddi tehdit veya tehlikelerin ortaya çıktı̆̆ olağanüstü durumlarda olağanüstü yönetim usullerine başvurulması, bu dönemde yürürlüğe konulan ve temel hak ve özgürlükleri sınırlandıran her düzenlemenin olağan dönemin izin verdiği ölçütlerin ötesinde olmasını gerektirmeyebilir. Anılan şekilde inceleme yapılması Anayasa'nın 15. maddesinde yer alan “.... Anayasada öngörülen güvencelere aykirı tedbirler alınabilir” hükmünün de bir gereğidir.” Bkz Anayasa Mahkemesi, 2016/205, 24.07.2019.
} 
- temel hak ve hürriyetlerin özüne dokunulmamalıdır,

- temel hak ve hürriyetler Anayasanın ilgili maddelerinde belirtilen sebeplere bağlı olarak sınırlandırılmalıdır,

- temel hak ve hürriyetler kanunla sınırlandırılmalıdır,

- Sınırlamaların Anayasanın sözüne ve ruhuna aykırı olmaması gerekmektedir,

- sinırlamaların demokratik toplum düzeninin gereklerine aykırı olmaması gerekmektedir,

- sınırlamaların laik Cumhuriyetin gereklerine aykırı olmaması gerekmektedir,

- sınırlamaların ölçülülük ilkesine aykırı olmaması gerekmektedir.

13. maddede söz konusu koşulların hangi sırayla inceleneceğine dair bir belirleme bulunmamaktadır. ${ }^{4}$ Anayasa Mahkemesinin norm denetimi ile ilgili kararlarına bakıldığında, anayasaya aykırılık iddiasına bağlı olarak, 13. maddede belirtilen ölçütler bakımından özel bir sıralama gözetilmeksizin inceleme yapıldığı görülmektedir. ${ }^{5}$ Bireysel başvurularla ilgili kararlarda ise kanunilik şartının öze dokunma, ölçülülük ve demokratik toplum düzeni ile ilgili koşullardan önce incelendiği ve kanunilik şartının sağlanmaması halinde diğer üç koşula ilişkin inceleme yapılmadı̆̆ı tespit edilebilir. Mahkemenin belirttiği üzere, “(...) denetim sırasında Anayasa Mahkemesi öncelikle müdahalenin kanunilik şartına uyup uymadığını inceleyecektir. Zira kanuna dayanmayan bir müdahalenin, öze dokunmama, demokratik toplum düzeninin gereklerinden olma ve ölçülülük gibi diğer güvencelere uygun olup olmadiğ incelenmeden bir Anayasal hakkı veya özgürlüğ̈̈ ihlal ettiği sonucuna ulaşılacaktır. Bu sebeple ilk olarak kanunilik unsurunun değerlendirilmesi gerekir. Kanunilik şartının sağlanması halinde müdahalenin Anayasa'da öngörülen amaçla yapılıp yapılmadı̆̆ ve daha sonra da diğer koşullara uygunluk denetimi yapılmalıdır." Çalışmada COVID-19 sebebiyle getirilen sokağa çıkma kısıtlamalarının 13. maddede belirtilen iki koşula uygunluğu ayrıntılı olarak incelenecektir. Bu çerçevede sınırlamaların Anayasa'nın ilgili maddelerinde belirtilen sebeplere bağlı olup olmadığı ilk olarak ele alınacaktır. İkinci olarak kanunla sınırlama koşulunun gereklerinin yerine getirilip getirilmediği incelenecektir. Ardından diğer koşullara uygunluğun ayrıntılı olarak ele alınmasına gerek olmadığı ortaya konulacaktır.

\footnotetext{
Abdurrahman Eren, Anayasa Hukuku Ders Notları (Genel Esaslar-Türk Anayasa Hukuku) (On İki Levha 2018) 354; Kemal Gözler, İnsan Hakları Hukuku (Ekin 2017) 339.

Eren (n 4) 355.

6 Anayasa Mahkemesi, Bireysel Başvuru, 2014/256, 25.06.2014, § 79.
} 


\section{Sokağa Çıkma Kısıtlamalarının Anayasa'nın İlgili Maddelerinde Belirtilen Sebeplere Bağlılığı}

Yukarıda belirtildiği üzere, 1982 Anayasası temel hak ve hürriyetlerin, özlerine dokunulmaksızın yalnızca Anayasa'nın ilgili maddelerinde belirtilen sebeplere bağlı olarak sınırlandırılmasını öngörmektedir. Bu durumda ilk olarak yapılması gereken, sokağa çıkma kısıtlamalarının hangi hak ve hürriyetleri sınırlandırdığını tespit etmek olmalıdır.

Sokağa çıkma kısıtlamaları her şeyden önce 1982 Anayasası'nın 23. maddesinde güvence altına alınan seyahat hürriyetine bir müdahale niteliğindedir. ${ }^{7}$ Kısıtlamaların kişileri kısıtlı bir alanda "ihmal edilemeyecek bir süre" bulunmaya zorlaması halinde kişi özgürlüğü ve güvenliği hakkına da bir müdahalenin olduğu söylenebilir. ${ }^{8} \mathrm{Bu}$ çerçevede COVID-19 sebebiyle getirilen sokağa çıkma kısıtlamalarının, kısıtlama getirilen yerlerdeki kişilerin seyahat özgürlüğüne bir müdahale niteliği taşıdığı söylenebilir. Sokağa çıkmaları günlerce kısıtlanan 20 yaş altı ve 65 yaş üstü kişiler ile kronik hastalığı bulunanların da seyahat hürriyetinin yanı sıra kişi hürriyeti ve güvenliği hakkına müdahale edildiği sonucuna ulaşılabilir. ${ }^{9}$ Ayrıca eğitim gören bir öğrencinin eğitim aldığı yere gidememesi, işçinin işyerine gidememesi, alınan önlemleri protesto etmek isteyen kişilerin bir araya gelememesi, kişilerin sevdiklerini bayramda ziyaret edememesi ve diğer birçok yoksunluk; eğitim hakkını, çalışma hakkını, toplantı ve gösteri yürüyüşü yapma hakkını, özel hayatı, maddi ve manevi varlığı geliştirme hakkını ve diğer hak ve hürriyetleri etkilemektedir. Görüldüğü üzere seyahat hürriyeti ve kişi hürriyeti dışında bu hürriyetlere bağlı olarak diğer birçok hak ve özgürlük de sokağa çıkma kısıtlamalarından nasibini almaktadır. ${ }^{10}$ Ancak her bireyin müdahaleye maruz kalan hak ve hürriyetleri farklılık gösterebileceğinden sokağa çıkma kısıtlamalarının hemen herkes için etkilediği hak ve hürriyetleri ele almak çalışmanın arzu ettiği sonuca ulaşmak bakımından daha yerinde -aşağıda görüleceği üzere aynı zamanda yeterli- görünmektedir.

1982 Anayasası'nın herkesin yerleşme ve seyahat hürriyetine sahip olduğunu belirten 23. maddesinde, yerleşme hürriyetinin suç işlenmesini önlemek, sosyal ve ekonomik gelişmeyi sağlamak, sağliklı ve düzenli kentleşmeyi gerçekleştirmek ve kamu mallarını korumak; seyahat hürriyetininse, suç soruşturma ve kovuşturması sebebiyle ve suç işlenmesini önlemek amaçlarıyla kanunla sınırlanabileceği

\footnotetext{
Venedik Komisyonuna göre sokağa çıkma yasağının temel sonucu seyahat hürriyetinin kısıtlanmasıdır. Bkz European Commission For Democracy Through Law (Venice Commission), 'Turkey Opinion On The Legal Framework Governing Curfews', Adopted by the Venice Commission at its 107th Plenary Session (Venice, 10-11 June 2016) § 84, <https://www. venice.coe.int/webforms/documents/default.aspx?pdffile=CDL-AD(2016)010-e > Erişim Tarihi 20 Mayıs 2020.

$8 \quad$ Tolga Şirin, Özgürlük ve Güvenlik Hakkl: Anayasa Mahkemesine Bireysel Başvuru El Kitapları Serisi-1 (2. Bası, Avrupa Konseyi 2019) 34. Bu çerçevede seyahat hürriyeti ile kiși hürriyeti ve güvenliği hakkı arasındaki temel fark "derece ve yoğunluk farkı"dır. Bkz ibid 50-54. Ayrıca bkz European Commission For Democracy Through Law (Venice Commission) (n 7) § 90

9 Hatta söz konusu gruplar dışında bulunan kişiler için de bu durumun belli ölçüde geçerli olduğu ileri sürülebilir.

10 Bkz Selin Esen, Anayasa Hukuku Açısından Dolaşım Özgürlüğü (Yetkin 2014) 71
} 
belirtilmektedir. Maddenin devamında vatandaşın yurt dışına çıkma hürriyetinin, ancak suç soruşturması veya kovuşturması sebebiyle hâkim kararına bağlı olarak sinırlanabileceği de ifade edilmektedir. Görüldüğü üzere, seyahat ve yerleşme hürriyetine ilişkin maddede her iki hürriyetin kısıtlama sebepleri arasında salgın hastalık veya genel sağlığın korunması bulunmamaktadır. Hatta seyahat hürriyeti ile yurt dişına çıkma hürriyetinin suç soruşturması ve kovuşturması gibi "bireysel" sebeplerle sınırlanabileceği ifade edilmektedir.

1982 Anayasası'nın kişi hürriyeti ve güvenliğini düzenleyen 19. maddesinde ise hastalık yayabilecek bir kişinin bir müessesede tedavi, eğitim veya 1slahı için kanunda belirtilen esaslara uygun olarak alınan tedbirin yerine getirilmesi, kişi hürriyeti ve güvenliği hakkının bir istisnası olarak sayılmaktadır. Ancak bu maddenin hastalık yayabilecek kişiler için uygulanabilir nitelikte olduğu görülmektedir. Her ne kadar mevcut hastalığın özellikleri sebebiyle ülkedeki herkes "hastalık yayabilecek kişi”" olarak kabul edilebilirse de maddede bir müessesede tedavi, eğitim veya 1slahtan bahsedilmektedir. Haliyle 19. maddenin öngördüğü bu istisna hasta olup olmadığı belli olmaksızın belli yaş aralığında olan veya belli şehirlerde ikamet eden kişilerin sokağa çıkmasını kısıtlamanın sebebi olamaz. Üstelik maddenin devamında her ne sebeple olursa olsun hürriyeti kısıtlanan kişinin, kısa sürede durumu hakkında karar verilmesini ve bu kısıtlamanın kanuna aykırılığı halinde hemen serbest bırakılmasını sağlamak amacıyla yetkili bir yarg1 merciine başvurma hakkına sahip olduğu belirtilmektedir. Bu düzenleme de 19 . maddenin öngördüğü istisnanın daha ziyade "bireysel" özgürlükten yoksun kılmalar için tasarlandığını göstermektedir.

Görüldüğü üzere, ne yerleşme ve seyahat hürriyeti ne de kişi hürriyeti ve güvenliği bakımından salgın hastalık veya genel sağlı̆̆ın korunması bir sınırlama sebebi olarak ilgili maddelerde öngörülmemiştir. Bu çerçevede kişilerin kişi hürriyeti ve güvenliği ile yerleşme ve seyahat hürriyetlerinin salgın hastalık sebebiyle sınırlandırılamayacağı savunulabilir. Nitekim 2001 anayasa değişiklikleri ile birlikte 1982 Anayasası'ndaki genel sınırlama sebepleri ${ }^{11}$ kaldırılmış, yalnızca Anayasa'nın ilgili maddelerinde belirtilen sebeplere bağlı olarak sınırlandırma yapılabileceği öngörülmüştür.

Öğretiye bakıldığında, 2001 anayasa değişiklikleri ile birlikte ilgili maddesinde sınırlama sebebi öngörülmeyen temel hak ve özgürlüklerin sinırlandırılıp sınırlandırılmayacağı yahut başka bir maddede yer alan sınırlama sebebi ile sınırlandırılıp sınırlandırılmayacağına ilişkin iki temel görüşşsekillenmiş̧ir. Her iki

2001 değişikliklerinden önce 1982 Anayasası'nın 13. maddesi şu hükümleri içermekteydi: "Temel hak ve hürriyetler, Devletin ülkesi ve milletiyle bölünmez bütünlüğünün, millî egemenliğin, Cumhuriyetin, milli güvenliğin, kamu düzeninin, genel asayişin, kamu yararının, genel ahlâkın ve genel săğlğın korunması amacı ile ve ayrıca Anayasanın ilgili maddelerinde öngörülen özel sebeplerle, Anayasanın sözüne ve ruhuna uygun olarak kanunla sinırlanabilir. Temel hak ve hürriyetlerle ilgili genel ve özel sinırlamalar demokratik toplum düzeninin gereklerine ayklrı olamaz ve öngörüldükleri amaç dışında kullanılamaz. Bu maddede yer alan genel sınırlama sebepleri temel hak ve hürriyetlerin tümü için geçerlidir." 
görüş çalışma konusunu da ilgilendiren örnekler verdiğinden bu görüşlere alıntılar eşliğinde kısaca yer verilmesinde yarar bulunmaktadır.

Gözler'e göre, ilgili maddede sınırlama sebebi belirtilmemiş temel hak ve hürriyetlerin kanunla sınırlandırılması 1982 Anayasası'nın 13. maddesine aykırı olacaktır. ${ }^{12}$ Sinırlama sebebi öngörülen hakların da ilgili maddede belirtilmeyen sebeplere göre sınırlandırılması mümkün değildir: "Örneğin seyahat hürriyeti "suç işlenmesini önlemek" sebebiyle sinırlandırlabilecek (m.23/3), ama "genel sağlık" sebebiyle sınırlandırllamayacaktır. Çünkü Anayasanın 23 'üncü maddesinde "genel sağlık" sebebi sayılmamaktadır. Dolayısıyla artık bir yerde salgın hastalık çıkması durumunda orada "karantina” ilân edilmesi Anayasamızın 23 ve 13 'üncü maddelerine aykırı olacaktır."13

Karşı görüş ise ilgili anayasa maddesinde sınırlama sebeplerine yer verilmese dahi temelhakveözgürlüklerinnesnel sınırlarılduğunuvediğerhakveözgürlüklerleçatışma halinde pratik uyuşum ilkesi gereğince hak ve özgürlüklerin sınırlandırılabileceğini savunmaktadır. ${ }^{14}$ Sağlam'ın belirttiği üzere, “(...) 13. maddedeki genel sinırlama sebeplerinin kaldırılmış olması, artık bir bölgenin salgın hastalıkları önleme amacıyla karantinaya alınamıyacă̆ı anlamına gelmemektedir. Bu özgürlüklerle ilgili anayasa kuralları, salgın hastalık tehlikesi altında dahi seyahat ve yerleşme özgürlüklerine koruma sağlayacak bir nesnel içeriğe sahip değildir. Çünkü bu özgürlüklerin salgın hastalık tehlikesi altında kullanılması, seyahat ve yerleşme özgürlüğ̈̈nün norm alanı ile özgül bir bağlantı içinde olmayan ve bu norm alanlart ile sadece arızi ve tesadüfi bir bağlantı içinde kalan bir kullanım biçimidir." ${ }^{15}$ Benzer şekilde Esen de dolaşım hürriyetinin "niteliğinden kaynaklanan doğal sınırları" olduğunu belirtmektedir. ${ }^{16}$ $\mathrm{Bu}$ çerçevede yazar, sınırlama öngörülmese dahi hakların nesnel sınırları olduğunu

12 Bkz Kemal Gözler, Türk Anayasa Hukuku (3. Bas1, Ekin 2019) 318-319.

13 ibid 322. Ayrıca bkz Kemal Gözler, 'Anayasa Değişikliğinin Temel Hak ve Hürriyetlerin Sınırlandırılması Bakımından Getirdikleri ve Götürdükleri (Anayasanın 13’üncü Maddesinin Yeni Șekli Hakkında Bir İnceleme)', (2001) 4 Ankara Barosu Dergisi 53, 64-65; Kemal Gözler, '3 Ekim 2001 Tarihli Anayasa Değişikliği: Bir Abesle İştigal Örneği’ (2002) 19 Anayasa Yargısı Dergisi 326. Söz konusu görüşün eleştirisi için bkz Tolga Şirin, 'Tehlikeli Salgın Hastalıklarla Hukuksal Mücadeleye Anayasal Bir Giriş’, (2020) < https://www.academia.edu/42611036/TEHL\%C4\%B0KEL\%C4\%B0 SALGIN_HASTALIKLARLA_HUKUKSAL_M\%C3\%9CCADELEYE_ANAYASAL_B $\% \mathrm{C} 4 \%$ B0R_G\%C4\%B0R\%C 4

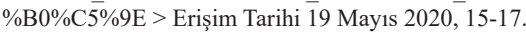

14 Örneğin bkz Abdurrahman Eren, Özgürlüklerin Sinırlandırllmasında Demokratik Toplum Düzeninin Gerekleri (Beta 2004) 76-77; Bülent Tanör ve Necmi Yüzbaşığlu, 1982 Anayasasına Göre Türk Anayasa Hukuku (19. Bası, Beta 2019) 146147; Eren (n 4) 364; Fazıl Sağlam, '2001 Yılı Anayasa Değişikliğinin Yaratabileceği Bazı Sorunlar ve Bunların Çözüm Olanakları' (2002) 19 Anayasa Yargısı Dergisi 288, 291; Fazıl Sağlam, Temel Hakların Sinırlanması ve Özü (AÜSBF 1982) 128-137; Sibel İnceoğlu, 'Hak ve Özgürlükleri Sınırlama ve Güvence Rejimi’ iç Sibel İnceoğlu (ed), İnsan Haklarl Avrupa Sözleşmesi ve Anayasa: Anayasa Mahkemesine Bireysel Başvuru Kapsamında Bir İnceleme (2. Bası, Beta 2013) 24-26. Ayrıca bkz Bertil Emrah Oder, Anayasa Yargısında Yorum Yöntemleri: Hukuksal Yöntembilime Dayalı Karşılaştırmalı Bir Araştırma (Beta 2010) 64 vd.

15 Sağlam, '2001 Y1lı Anayasa Değişikliğinin Yaratabileceği Bazı Sorunlar' (n 14) 294.

16 Esen (n 10) 149. 
ve diğer hak ve özgürlüklerle çatışma halinde sınırlanabileceğini ifade etmektedir. ${ }^{17}$ Eren ise Anayasa'nın 13. maddesinde ifade edilen, "Anayasanın ilgili maddelerinde belirtilen sebepler" ifadesinin tek bir maddeye değil, ilgili maddelere gönderme yaptığını belirtmekte; ilgili maddelerin ne olduğuna Anayasa'nın tamamı gözetilerek her somut olayda karar verilmesi gerektiğini ifade etmektedir. ${ }^{18}$

Anayasa Mahkemesinin konu ile ilgili kararlarına bakıldığında, istisnai nitelikteki birkaç karar ${ }^{19}$ dışında ikinci görüşün benimsendiği görülmektedir. Bu çerçevede Mahkeme ilk olarak, ele aldığı temel hak ve özgürlüğe ilişkin Anayasa maddesinde sınırlama sebebi yer alıp almadığını belirtmekte, sonrasında ise hakların "doğasından kaynaklanan bazı sınırlarının" olduğunu ve hakkı düzenleyen maddede herhangi bir sınırlama nedenine yer verilmemiş olsa da Anayasa'nın başka maddelerinde yer alan kurallara dayanılarak hakların sınırlandırılmasının mümkün olduğunu ifade etmektedir: "Anayasa Mahkemesinin birçok kararında da belirtildiği gibi temel hak ve hürriyetlerin doğasından kaynaklanan bazı sinırları bulunduğu gibi Anayasa'nın başka maddelerinde yer alan kurallar da temel hak ve hürriyetlerin doğal sınırını oluşturur. Bir başka deyişle, temel hak ve özgürlüklerin kapsamının ve objektif uygulama alanının her bir norm yönünden bă̆ımsız olarak değil Anayasa'nın bütünü içerisindeki anlama göre belirlenmesi gerekir. Dolayısıyla Anayasa'nın diğer hükümlerinin gerektirmesi nedeniyle düzenlendiği maddede hiçbir sinırlama nedenine yer verilmeyen hakların da sinırlanabilmesi veya maddelerinde belirtilen nedenler dişında diğer anayasal nedenlere dayalı olarak sinırlama yapılabilmesi mümkün bulunmaktadır." $20 \mathrm{Bu}$ çerçevede Mahkeme hem norm denetimi

\footnotetext{
ibid 202. Bu hususta ayrıca bkz H. Tahsin Fendoğlu, '2001 Anayasa Değişikliği Bağlamında Temel Hak Ve Özgürlüklerin Sınırlanması (Ay. Md.13.)' (2002) 19 Anayasa Yargısı Dergisi 178; Mehmet Sağlam, 'Ekim 2001 Tarihinde Yapılan Anayasa Değişiklikleri Sonrasında, Düzenlendikleri Maddede Hiçbir Sınırlama Nedenine Yer Verilmemiş Olan Temel Hak ve Özgürlüklerin Sınırı Sorunu' (2002) 19 Anayasa Yargısı Dergisi 233; Nihat Bulut, ‘4709 sayılı Kanunla Yapılan Anayasa Değişikliği Çerçevesinde Hak ve Özgürlüklerin Sınırlanması Rejiminin Birey Devlet İlişkisi Açısından Değerlendirilmesi’ (2001) 5(1-4) Atatürk Üniversitesi Erzincan Hukuk Fakültesi Dergisi 37; Zühtü Arslan, 'Temel Hak ve Özgürlüklerin Sınırlanması: Anayasa'nın 13. Maddesi Üzerine Bazı Düşünceler’ (2002) 19 Anayasa Yargısı Dergisi 216.

18 Eren (n 4) 368.

19 “Anayasa'nın 13. maddesine göre temel hak ve özgürlüklerin stnırlandırlması ancak ilgili maddelerinde belirtilen sebeplere bağlı olup, Anayasa'nın 36. maddesinde böyle bir sinırlandırma öngörülmemiştir (...) Bu nedenlerle kural Anayasa'nın 36. maddesine ayktrıdır. Iptali gerekir." Bkz Anayasa Mahkemesi, 2000/48, 20.03.2002. Benzer yönde: Anayasa Mahkemesi, 2001/5, 28.03.2002. “Yurt dışına çıkma özgürlüğü sadece Anayasa'nın 23. maddesinde sayılan özel sinırlama nedenlerine bağl olarak sınırlandırllabilecektir. 23. maddede yurt dışına çıkma yasağıyla ilgili sinırlama nedenleri vatandaşlık ödevi ve ceza soruşturması veya kovuşturması olarak gösterilmiştir. Anayasa'da sınırlama nedenlerinin sayılarak belirlenmiş olması, yasa koyucunun bunlar dışında kalan bir nedenle yurt dışına çıkma özgürlüğünün sınırlanması sonucunu doğuracak düzenlemeler yapamayacağını göstermektedir.” Bkz Anayasa Mahkemesi, 2007/4, 18.10.2007; Anayasa Mahkemesi, 2008/66, 22.07.2008. "Anayasa'da sınırlama nedenlerinin sayllarak belirlenmiş olmasl, yasakoyucunun bunlar dışında kalan bir nedenle yerleşme özgürlüğünün sınırlanması sonucunu doğuracak düzenlemeler yapamayacağını göstermektedir. Dava konusu kurallarda belirtilen "millî güvenlik", yerleşme özgürlüğüyle ilgili sınırlama nedenleri arasında saylmamıştır. Anayasa'nın ilgili maddesinde gösterilen sinırlama nedenlerine dayandırlmayan kuralla, aile veya fertlerin millî güvenlik nedeniyle zorunlu iskâna tabi tutulması, Anayasa'nın 23. maddesinin güvence altına aldığı yerleşme özgürlüğü alanına yapılan açık müdahale niteliğindedir. Bu nedenlerle, dava konusu kurallar Anayasa'nın 13. ve 23. maddelerine aykırıdır ve iptalleri gerekir." Bkz Anayasa Mahkemesi, 2006/142, 24.09.2008. Öte yandan Anayasa Mahkemesi genel nüfus sayımlarında sokağa çıma yasağı konulmasına ilişkin normun anayasallığını incelediği bir kararda, sokağa çıkma yasağının 19. ve 23. maddelerde belirtilen sınırlamalar içerisinde yer almadığını da ifade etmiştir. Bkz Anayasa Mahkemesi, 2000/82, 26.11.2002. Bu kararda Mahkeme, genel nüfus sayımlarında sokağa çıkma yasağı konulmasına ilişkin düzenlemeyi iptal etmekle birlikte iptal gerekçesi, söz konusu düzenlemenin (eski) 91. madde gereği KHK ile yapılmasının mümkün olmaması olmuştur.

20 Anayasa Mahkemesi, 2014/176, 27.05.2015.
} 
kararlarında hem de bireysel başvurularla ilgili verdiği kararlarda benzer ifadeleri kullanmaktadır. ${ }^{21}$ Üstelik Mahkeme sinırlama sebebi bulunmayan temel hak ve hürriyetler sınırlandırıldığında yahut hakkın veya hürriyetin düzenlendiği maddede belirtilen sınırlama sebebi dışında bir sebeple sınırlama yapıldığında, sınırlama sebebinin temel hak ve hürriyetlere ilişkin maddelerde yer almasının zorunlu olmadığ 1 kanaatindedir. Bu çerçevede Cumhuriyetin nitelikleri ya da devlete yüklenen ödevler, hak ve hürriyetleri sınırlandırma sebebi olarak kabul görebilmektedir. ${ }^{22}$

Sonuç olarak, öğretinin çoğunluğu ve Anayasa Mahkemesi, temel hak ve hürriyetlerin kendi sınırları olduğunu, bunların düzenlendikleri Anayasa maddesi dışındaki maddelerde belirtilen sebeplerle sınırlanabileceğini kabul etmektedir. $\mathrm{Bu}$ çerçevede müdahale edilen hak ve hürriyete ilişkin belirtilen özel sınırlama sebepleri dışında, genel sağlığın korunması, kamu düzeni, devletin temel amaç ve görevlerini düzenleyen 5. madde, herkesin yaşam hakkına sahip olduğunu belirten 17. madde ile sağlıklı ve dengeli bir çevrede yaşama hakkına ilişkin 56. madde COVID-19 sebebiyle getirilen sokağa çıkma kısıtlamalarının sebepleri olarak gösterilebilir. ${ }^{23}$

\section{Sokağa Çıkma Kısıtlamalarının Kanunilik İIkesine Uygunluğu}

COVID-19 sebebiyle getirilen sokağa çıkma kısıtlamalarının Anayasa'nın ilgili maddelerinde belirtilen sebeplere bağlı olarak getirildiğini -tartışmalı da olsa- tespit ettikten sonra sıra, kanunilik ilkesi çerçevesinde inceleme yapmaya gelmektedir. 1982 Anayasası'nın 13. maddesi gereğince temel hak ve hürriyetler, ancak kanunla sınırlanabilir. Bu çerçevede anlaşılması gereken Türkiye Büyük Millet Meclisi tarafından yapılan şekli anlamda kanundur. Ancak kanunilik ilkesi kanunun şekli

21 Manevi varlığın korunması ve geliştirilmesi hakkı açısından bkz Anayasa Mahkemesi, Bireysel Başvuru, 2013/2187, 19.12.2013, § 33. Özel ve aile hayatına saygı hakkı bakımından bkz Anayasa Mahkemesi, Bireysel Başvuru, 2014/18849, 11.01.2017; Anayasa Mahkemesi, Bireysel Başvuru, 2016/8080, 26.12.2019, § 48; Anayasa Mahkemesi, 2014/176, 27.05.2015. Hak arama hürriyeti ile ilgili olarak bkz Anayasa Mahkemesi, Bireysel Başvuru, 2015/3324, 26.02.2020, § 42; Anayasa Mahkemesi, Bireysel Başvuru, 2017/21973, 11.12.2019, § 35; Anayasa Mahkemesi, 2016/37, 14.07.2016; Anayasa Mahkemesi, 2015/96, 10.02.2016; Anayasa Mahkemesi, 2010/83, 01.11.2012; Anayasa Mahkemesi, 2012/35, 27.12.2012; Anayasa Mahkemesi, 2017/24, 14.06.2017. Özel hayatın gizliliği ile ilgili bkz Anayasa Mahkemesi, Bireysel Başvuru, 2016/8080, 26.12.2019, § 48. Çalışma ve sözleşme hürriyeti ile ilgili olarak bkz Anayasa Mahkemesi, 2011/150, 14.02.2013; Anayasa Mahkemesi, 2014/87, 08.12.2015.

22 “(...) Anayasa'nın başka maddelerinde yer alan hak ve özgürlükler ile devlete yüklenen ödevler özel sinırlama sebebi gösterilmemiş hak ve özgürlüklere sinır teşkil edebilir." Bkz Anayasa Mahkemesi, 2018/73, 24/07/2019. "Özürlü ve eski hükümlü çallşstırma yükümlülüğü, ruhsal veya fiziksel açıdan yetersizliği nedeniyle yahut işlemiş olduğu bir suç dolaylslyla aldığı cezadan dolayı iş bulma imkanını önemli ölçüde yitirenleri koruma düşüncesine dayanmaktadır. Anayasa'nın 50. maddesinin ikinci fikrasındaki "Küçükler ve kadınlar ile bedeni ve ruhi yetersizliği olanlar çalışma şartları bakımından özel olarak korunurlar." hükmü özürlülerin özel olarak himaye edilmesini güvence altına aldığından kural, özürlüler bakımından Anayasa'nın 50. maddesinin bir gereğidir (...) Anayasa'nın 61. ve 48. maddelerindeki Devlete verilen söz konusu yükümlülükler birlikte değerlendirildiğinde, özel ve kamu ayırımı yapılmaksızın özürlü ve eski hükümlü çalıştırılma zorunluluğu öngörülen kuralın, sosyal amaçları gözettiği ve sosyal devlet ilkesinin bir sonucu olduğu, ayrıca kuralda özel kesim açısından bir ölçüsüzlükten de söz edilemeyeceği anlaşılmaktadır.” Bkz Anayasa Mahkemesi, 2006/101, 19.06.2008. Söz konusu kararın eleştirisi için bkz Gözler (n 4) 358-359; Tamer Bozkurt, ‘Anayasa Mahkemesi'nin 4857 Sayılı İş Kanunu'ndaki Engelli ve Eski Hükümlü Çalıştırma Zorunluluğunun Anayasa’ya Uygun Olduğuna Dair Verdiği Karar Üzerine Düşünceler' (2009) 2 Ankara Barosu Dergisi 98.

23 Esen de Anayasa'nın 17. ve 56. maddeleri hükümlerine dayanılarak seyahat özgürlüğünün sınırlandırılmasının mümkün olduğunu belirtmektedir. Yazar ayrıca "ölümcül salgınlar" sebebiyle tehlikeye düşebilecek başkalarının yaşamlarının güvence altına alınması amacıyla da dolaşım özgürlüğünün kısıtlanmasının mümkün olduğunu ifade etmektedir. Bkz Esen (n 10)160. 
anlamda varlığıyla yetinmemekte, içerik bakımından da belli özelliklere sahip olmasını gerektirmektedir. Anayasa Mahkemesi de şekli anlamda kanunun gerekli ancak yetersiz olduğunu belirtmekte, "kanunun kalitesinin" de kanunilik koşulunun sağlanıp sağlanmadığının tespitinde önem arz ettiğini kabul etmektedir. Bu bakımdan kanuni düzenleme ulaşılabilir, belirli ve öngörülebilir olmalıdır. ${ }^{24}$ Bir diğer deyişle, Anayasa'nın 13. maddesinin aradığ anlamda kanun, “(..) kamu gücünü kullanan organların keyfi davranışlarının önüne geçen ve kişilerin hukuku bilmelerine yardımcı olacak, erişilebilir, öngörülebilir ve kesin nitelikte" olmalıdır. ${ }^{25}$

Anayasa Mahkemesine göre ulaşılabilirlik ilgili kanunun aleni olmasını yani yayımlanmasını ifade etmektedir. ${ }^{26}$ Türkiye'de tüm kanunlar Resmi Gazete'de yayımlandığından bu koşulun gerçekleşmesi bakımından bir sorunun ortaya çıkması zor gözükmektedir. ${ }^{27}$ Belirlilik bakımından, Mahkemenin 2014 yılında kabul edilen 6552 sayılı Kanun'la ilgili iptal gerekçesi yol gösterici olabilir. İptal davasına konu olan kural, internet trafik bilgisinin Telekomünikasyon İletişim Başkanlığı tarafından ilgili işletmecilerden herhangi bir hukuki inceleme ya da sürece dahil olmadan alınmasını ve hâkim tarafından karar verilmesi durumunda bu bilginin ilgili mercilere verilmesini düzenlemektedir. Mahkeme söz konusu kuralla ilgili verdiği iptal kararında, "Kuralda, temin edilecek bilgiyle ilgili olarak herhangi bir konu ve amaç sinırlaması bulunmadiğı gibi bilginin kapsamı, ne şekilde kullanılacağı, tutulacağ süre, temin edilme gerekçesi gibi hususlarla ilgili olarak da herhangi bir belirlilik bulunmamaktadır." ${ }^{28}$ ifadelerini kullanmıştır. O halde temel hak ve özgürlüklere müdahale durumunda müdahalenin kapsamı, ne şekilde olacağı, süresi gibi temel konuların belirlilik ilkesi gereğince kanunda yer alması gerektiği söylenebilir.

Belirlilikle sık1 sıkıya bağlantılı öngörülebilirlik ${ }^{29}$ ise kanuni düzenlemenin muhatabı tarafindan kavranma derecesi ile ilgilidir. Anayasa Mahkemesinin ses getiren Youtube kararında ifade ettiği gibi, “(...) İdari işlemle engellemenin URL bazlı değil de tüm siteye erişimin engellenmesi şeklinde yapılabileceğine ilişkin bir düzenlemeye Kanun'un herhangi bir hükmünde yer verilmediği, ayrıca idarece bu konudaki yetkinin hangi sınırlama araçları (alan adından erişimin engellenmesi, IP adresinden erişimin engellenmesi, içeriğe erişimin engellenmesi ve benzeri

\footnotetext{
Güncel kararlardan örnekler için bkz Anayasa Mahkemesi, Bireysel Başvuru, 2017/4483, 13.02.2020; Anayasa Mahkemesi, Bireysel Başvuru, 2016/67737, 19.11.2019; Anayasa Mahkemesi, Bireysel Başvuru, 2016/15421, 12.11.2019.

25 Bkz Anayasa Mahkemesi, Bireysel Başvuru, 2014/256, 25.06.2014, § 91

26 Anayasa Mahkemesi, Bireysel Başvuru, 2014/6193, 15.10.2015, § 49.

27 Anayasa Mahkemesi de birçok kararda “(...) Kanun hükümlerinin Resmî Gazete’de yayımlandıkları dikkate alındı̆̆ında yeterince ulaşılabilir olduklarında kuşku bulunmamaktadır.” ifadesini kullanmaktadır. Örneğin bkz Anayasa Mahkemesi, Bireysel Başvuru, 2017/32754, 10.03.2020, § 32.

28 Anayasa Mahkemesi, 2014/149, 02.10.2014. Benzer yönde bkz Anayasa Mahkemesi, 2014/87, 08.12.2015.

29 “Anayasal haklara yönelik müdahalenin bir kanuna dayanması yeterli olmayıp, bu kanunun belirlilik ve öngörülebilirlik gibi belli niteliklere sahip olması gerekir. Başka bir ifadeyle kanun, ilgili kişinin davranışlarını belirlemesi amacıla, kolayca ulaşabileceği, gerektiğinde profesyonel yardım almak suretiyle de olsa anlayabileceği, açı, net ve yeterince belirgin nitelikte olmalıdır." Anayasa Mahkemesi, 2014/87, 08.12.2015, § 232.
} 
yöntemlerle erişimin engellenmesi) kullanılarak erişimin engelleneceğinin tam bir açıklıkla ortaya konulmadiğı, dolayısıyla idareye verilen yetkinin kapsam ve sinırlarının öngörülemez olduğu anlaşllmaktadır. Ayrıca, Kanun'un 9. maddesinin (4) numaral fikrasinda hâkime kademeli olarak erişimin engellenmesi konusunda verilen yetkiye benzer tarzda bir yetkinin kamu idaresi açısından da geçerli olup olmadı̆̆ belirgin değildir. Bu nedenle TïB'e erişimin engellenmesine yönelik olarak verilen yetkinin kanuni dayanağının kanunilik ilkesinin asgari şartı olan kanunun anlaşıllır, açı ve net olması zorunluluğunu karşılamaması nedeniyle kapsam ve sınırlarının belirsiz olduğu görülmektedir. Yukarıda yapılan açıklamalardan, youtube. com sitesine erişimin tümüyle engellenmesine yönelik müdahalenin, yeterince açı ve belirgin bir kanuni dayanağa sahip olmadiğı ve bu yönüyle başvurucular açısından öngörülebilir nitelikte bulunmadığı anlaşılmaktadır." ${ }^{30}$ Görüldüğü üzere, belirlilikle ayrışmaz bir şekilde bağlı olan öngörülebilirlik, normun uygulanmasının ardından ortaya çıkan netice ile normun muhataplarının "beklentisi" arasındaki yakınlığa bakmaktadır. Diğer bir deyişle hukuk kuralının uygulanması hâlinde doğabilecek sonuçların, önceden tahmin edilebilmesini ifade etmektedir. ${ }^{31}$

Kanunilik ilkesinin şekli anlamda kanunla yetinmemesinin ve yukarıda belirtilen "kalite standartlarını" aramasının belirli sonuçları bulunmaktadır. Bu çerçevede ilk olarak belirtilmesi gereken, sınırlama getiren kanunların uygulayıcıların kişisel görüşlerine göre şekillenecek şekilde açıklık ve kesinlik taşımayan düzenlemeler içermesi halinde kanunilik ilkesinin gereklerinin yerine gelmeyecek olmasidır. ${ }^{32}$ Zira kanunların uygulanma şekli yürütme organının insafına bırakılmış, dilenildiği ölçüde inisiyatif kullanılacak bir husus değildir. ${ }^{33}$ Hürriyet asıl, sınırlama istisna olduğundan sınırlamaların açıkça öngörülmesi gerekmekte, hürriyetlerin örtülü olarak sınırlandırılması mümkün olmamalıdır. ${ }^{34}$

İkinci olarak, kanunlarda temel hak ve özgürlüklerin sınırlandırılması öngörülmüş olsa dahi bu amaçla tanınan yetkilerin dar yorumlanması gerekmektedir. Özellikle tanınan yetkinin belli bir şeyi yapabilmeyi içerip içermediği hususunda tereddüt doğarsa, potestas stricte interpretatur ilkesi gereğince yetkinin söz konusu şeyi yapabilmeyi içermediği kabul edilmelidir. ${ }^{35} \mathrm{Bir}$ diğer sonuç ise kanunla getirilmeyen bir sınırlamanın idari işlemlerle getirilmesinin mümkün olmamasıdır. ${ }^{36}$ Temel hak ve özgürlüklerin sınırlanması söz konusu olduğunda, yürütme organının

\footnotetext{
Anayasa Mahkemesi, Bireysel Başvuru, 2014/4705, 29.05.2014, § 63-64.

Anayasa Mahkemesi, Bireysel Başvuru, 2014/6193, 15.10.2015, § 50.

Eren (n 4) 359. Ayrica bkz Eren (n 14) 70.

33 Ömer Anayurt, Anayasa Hukuku Genel Klsım (Temel İlkeler, Kavram ve Kurumlar) (2. Bası, Seçkin 2019) 616.

34 Kemal Gözler, Anayasa Hukukunun Genel Teorisi - Cilt I (Ekin 2011) 302. Ayrıca bkz Kemal Gözler, Anayasa Hukukunun Genel Teorisi - Cilt II (Ekin 2011) 505-506.

35 Gözler, Anayasa Hukukunun Genel Teorisi - Cilt I (n 34) 300-301.

36 Eren (n 4) 360 .
} 
gerçekleştireceği işlemler ancak "kullanımla ilgili biçimsel"37 işlemler olabilir. Haliyle yürütme organı yeni bir sınırlama getirmek veya var olan sinırlamanın kapsamını genişletmekten ziyade kanunda öngörülen sınırlamanın uygulanmasını gerçekleştirebilir. ${ }^{38}$ Anayasa Mahkemesinin 1srarla vurguladı̆̆ 1 gibi, “(...) temel hak ve özgürlüklerin sınırlandırılmasına yönelik yapılacak kanuni düzenlemelerde kanun koyucunun temel esaslar, ilkeleri ve çerçeveyi belirledikten sonra diğer ayrıntıların düzenleyici işlemler ile belirlenebileceği kabul edilmiştir. Aksi bir durum temel hak ve özgürlüklerin ancak kanunla sınırlanabileceğine ilişkin Anayasa'nın 13. maddesi hükmüne de aykırılık oluşturacaktır."39

Giriş kısmında belirtildiği üzere, sokağa çıkma kısıtlamaları öngören genelgelerin dayanağı olarak İl İdaresi Kanunu'nun 11. maddesinin C fikrası ile Umumi Hıfzısıhha Kanunu'nun 27. ve 72. maddeleri gösterilmektedir. Aşağıda her iki kanunun ilgili maddelerinin sokağa çıkma kısıtlamaları bakımından kanunilik ilkesinin gereklerini karşılayıp karşılamadı̆̆ı incelenecektir.

\section{1. İl İdaresi Kanunu}

İl İdaresi Kanunu'nun 11. maddesinin C fikrasına dayanılarak sokağa çıkma kısıtlamaları gerçekleştirilmesi, COVID-19 salgınından önce de söz konusu olmuştur. Bu çerçevede özellikle 2015 yılının Eylül - Aralık ayları arasında Güneydoğu'da uygulanan sokağa çıkma kısıtlamaları akıllara gelebilir. Üstelik söz konusu tarihlerde İl İdaresi Kanunu'nun 11. maddesinin C fikrası çok daha kısa ve genel bir düzenleme içermekteydi: "Ill sınırları içinde huzur ve güvenliğin, kişi dokunulmazlı̆̆ının, tasarrufa müteaallik emniyetin, kamu esenliğinin să̆lanması ve önleyici kolluk yetkisi valinin ödev ve görevlerindendir. Bunları sağlamak için vali gereken karar ve tedbirleri alır. Bu hususta alınan ve ilan olunan karar ve tedbirlere uymiyanlar hakkında 66 ncı madde hükmü uygulanır."40

Söz konusu dönemde uygulanan sokağa çıkma kısıtlamalarının olağanüstü hâl ilanı olmaksızın İl İdaresi Kanunu'na dayanılarak gerçekleştirilmesi birçok eleştiriye sebep olmuş, getirilen kısıtlamaların Anayasa'ya aykırı olduğu ileri sürülmüştür. ${ }^{41} \mathrm{Bu}$

\footnotetext{
Tanör ve Yüzbaşığlu (n 14) 158.

38 Gözler (n 4) 227; Gözler (n 12) 311.

39 Anayasa Mahkemesi, Bireysel Başvuru, 2016/7628, 27.02.2020; Anayasa Mahkemesi, Bireysel Başvuru, 2017/16005, 11.12.2019; Anayasa Mahkemesi, Bireysel Başvuru, 2013/6693, 16.04.2015. Ayrıca bkz Anayasa Mahkemesi, Bireysel Başvuru, 2014/16877, 22.03.2018; Anayasa Mahkemesi, Bireysel Başvuru, 2014/2889, 25.01.2018; Anayasa Mahkemesi, Bireysel Başvuru, 2013/7666, 10.12.2015.

40 İl İdaresi Kanunu'nun son değişiklikler öncesi metnine TBMM Mevzuat Bilgi Sistemi üzerinden ulaşılmıştır. Bkz $<$ https:// mevzuat.tbmm.gov.tr/mevzuat/faces/kanunmaddeleri?pkanunlarno=41587\&pkanunnumarasi=54 $42>$ Erişim tarihi 18 Mayis 2020.

41 Bkz Artuk Ardıçoğlu, 'Hukuka Uygun Olmayan Sokağa Çıkma Yasağı Hukuka Aykırı Mıdır?' (Birikim Dergisi, 27 Kasım $2015)<$ https://www.birikimdergisi.com/guncel/7331/hukuka-uygun-olmayan-sokaga-cikma-yasagi-hukuka-aykiri-midir > Erişim Tarihi 25 Mayıs 2020. Emine Cin Karagöz, 'Özel Güvenlik Bölgesi ve Sokağa Çıkma Yasağı İlanının Hukuki Niteliği ve Uygulamadan Kaynaklı Sorunlar' (2016) 20(2) Gazi Üniversitesi Hukuk Fakültesi Dergisi 625; Gözler (n 12) 1004; Tolga Şirin, 'Eine Ausgangssperre Ohne Ausnahmezustand?' (2015) 4(7) Anayasa Hukuku Dergisi 275.
} 
çerçevede İl İdaresi Kanunu'nun ilgili düzenlemelerinin Anayasa'nın 13. maddesinin aradığı kanunilik koşulunu sağlamadığı $1{ }^{42}$ kanunda sokağa çıkma kısıtlaması getirme yetkisi tanınmadığ ${ }^{43}$ savunulmuştur. Hatta Güneydoğu'da "anayasal olmayan bir olağanüstü hâl" söz konusu olduğu dahi dile getirilmiştir. ${ }^{44}$

İl İdaresi Kanunu'na dayanılarak uygulanan sokağa çıkma kısıtlamaları ile ilgili hazırladığı raporda Venedik Komisyonu da benzer eleştiriler getirmiştir. Komisyona göre sokağa çıkma kısıtlamalarının dayană̆ı olan söz konusu kanun ile kısıtlamaya ilişkin kararlar, Türkiye'nin 1982 Anayasası ve Avrupa İnsan Hakları Sözleşmesi başta olmak üzere temel hak ve hürriyetlere ilişkin uluslararası yükümlülüklerinde yer alan kanunilik ilkesinin gereklerini karşılamamaktadır. ${ }^{45} \mathrm{Bu}$ çerçevede Komisyon, İl İdaresi Kanunu'na dayanılarak sokağa çıkma kısıtlaması uygulamalarına son verilmesini, sokağa çıkma yasağı gibi olağanüstü önlemler alınacaksa bunların ulusal kurallar ve uluslararası yükümlülüklerle uyumlu şekilde gerçekleştirilmesi gerektiğini vurgulamıştır. ${ }^{46}$ Komisyonun temel eleştirileri, dayanak kanunda sokağa çıkma kısıtlamaları ile ilgili hukuki çerçevenin çizilmemiş olması, kısıtlamalar esnasında hangi önlemlerin alınacağının belirsiz olması ve getirilen sınırlamaların Anayasa ve uluslararası yükümlülüklerle uyumlu olmasının ne şekilde sağlanacağına ilişkin güvencelerin yer almaması üzerine olmuştur. ${ }^{47}$ Sonuç olarak, sokağa çıkma kısıtlamalarının dayanağı olarak gösterilen İl İdaresi Kanunu'ndaki hükümlerin kanunun kalitesi, öngörülebilirlik ve hukuki belirlilik açısından ciddi sorunlar içerdiği ve kısıtlamaların kanunla öngörülme koşulunu taşımadığı savunulmuştur. ${ }^{48}$

Kanun koyucu yapılan eleştirileri haklı görmüş olmalı ki 2018 yılında kabul edilen 7145 sayılı Kanun'la İl İdaresi Kanunu'nun 11. maddesinin C fikrasında eklemeler ve değişiklikler yapılarak madde çok daha ayrıntılı düzenlemeleri içerir hale getirilmiştir. Günümüzde yürürlükte olan ve COVID-19' la mücadele çerçevesinde ilan edilen sokağa çıkma kısıtlamaları genelgelerinin dayanağı olan düzenleme şu şekildedir:

\footnotetext{
2 Ece Göztepe, 'Ein Paradigmenwechsel für den Sicherheitsstaat: Die Praxis des Ausnahmezustandes im Südosten der Türkei' iç Matthias Lemke (ed), Ausnahmezustand: Theoriegeschichte - Anwendungen - Perspektiven (Springer VS 2017) 119. Belirtmek gerekir ki söz konusu sokağa çıkma kısıtlamalarında dayanak olarak İl İdaresi Kanunu m. 11/C'nin yanı sıra ilçe sınırları içinde huzur ve güvenliğin, kişi dokunulmazlığının, tasarrufa mütaallik emniyetin, kamu esenliğinin sağlanmasının ve önleyici kolluk yetkisinin kaymakamın ödev ve görevlerinden olduğunu ve bunları sağlamak için kaymakamın gereken karar ve tedbirleri alacağını belirten 32/Ç maddesine de dayanılmıştır.

43 Şirin (n 41) 280-282. Ardıçoğlu'nun ifadesiyle, “(...) idare belirli bir işlemi yapma konusunda "takdir yetkisine” sahip olmakla birlikte, o işlemin ne olduğunu "tayin etme yetkisine” sahip değildir. Bu, Anayasa madde 123/1'de düzenlenmiş olan "kanuni idare" ilkesinin temel sonucudur. Maddelerde yer alan "gereken" ifadesi kanunların öngörmüş olduğu sonuçlardan birini seçme konusundadır." Bkz Ardıçoğlu (n 41).

44 Göztepe (n 42) 123. Benzer yönde: Şirin (n 41) 282.

45 European Commission For Democracy Through Law (Venice Commission) (n 7) § 99.

46 ibid $\S 100$.

47 ibid $\S 92$.

48 ibid $\S 85-86$.
} 
"Ill slnırları içinde huzur ve güvenliğin, kişi dokunulmazlı̆ğnın, tasarrufa müteaallik emniyetin, kamu esenliğinin sağlanmast ve önleyici kolluk yetkisi valinin ödev ve görevlerindendir. Bunları sağlamak için vali gereken karar ve tedbirleri alır.

Vali, kamu düzeni veya güvenliğinin olağan hayatı durduracak veya kesintiye uğratacak şekilde bozulduğu ya da bozulacağına ilişkin ciddi belirtilerin bulunduğu hâllerde on beş günü geçmemek üzere ildeki belirli yerlere girişi ve çıkışı kamu düzeni ya da kamu güvenliğini bozabileceği şüphesi bulunan kişiler için sinırlayabilir; belli yerlerde veya saatlerde kişilerin dolaşmalarını, toplanmalarını, araçların seyirlerini düzenleyebilir veya kisıtlayabilir ve ruhsatl da olsa her çeşit silah ve merminin taşınması ve naklini yasaklayabilir.

Bu fikra kapsamında alinan ve ilan olunan karar ve tedbirlere uymıyanlar hakkinda 66 ncı madde hükmü uygulanır."

Görüldüğü üzere 2018 yılında yapılan değişikliklerle İl İdaresi Kanunu'nun 11. maddesinin C fikrası daha ayrıntılı hale getirilmiş ve özellikle eklenen ikinci paragraf ile valilere oldukça geniş yetkiler verilmiştir. Ancak söz konusu düzenlemenin sokağa çıkma kısıtlamalarına dayanak olması bu haliyle de mümkün gözükmemektedir.

Fıkranın ilk bendinde valilerin görev ve yetkileri genel olarak belirtilmektedir. Bu bakımdan ilk bent ile karar ve tedbirlere uymayanlar hakkında 66. maddenin uygulanacağını belirten üçüncü bent, 2018 değişikliklerinden önce 11. maddenin C fikrasının tamamını oluşturmaktaydı. Venedik Komisyonu ve öğretinin eleştirileri ile kanun koyucunun fikrayı genişletmesi göz önüne alındığında sokağa çıkma kısıtlamalarının birinci ve üçüncü bentlere dayandırılamayacağı anlaşılmaktadır. $\mathrm{Bu}$ durumda COVID-19 sebebiyle uygulanan sokağa çıkma kısıtlamalarının dayanağı fikranın ikinci bendi olabilir. İkinci bentte ilk olarak, kamu düzeni ya da kamu güvenliğini bozabileceği şüphesi bulunan kişiler için ildeki belirli yerlere giriş ve çıkışın sınırlandırılabileceğinden bahsedilmektedir. Sokağa çıkma kısıtlaması getirilen şehirlerdeki herkesin hastalık taşıma ya da yayma bakımından kamu düzeni ya da kamu güvenliğini bozabileceği şüphesi olsa dahi belirli yerlere giriş ve çıkışın sınırlandırılmasından bahsedildiğinden genel sokağa çıkma kısıtlamalarının dayanağı ikinci bentteki bu düzenleme olamaz. O halde bentte (araçlara, silah ve mermilere ilişkin ifade bir tarafa bırakılırsa) sokağa çıkma kısıtlamasına dayanak olabilecek tek yetki kalmaktadır: Vali, kamu düzeni veya güvenliğinin olağan hayatı durduracak veya kesintiye uğratacak şekilde bozulduğu ya da bozulacağına ilişkin

\footnotetext{
49 İl İdaresi Kanunu'nun 66. maddesi uyarınca, "Ill genel kurulu veya idare kurullarl yahut en büyük mülkiye amirleri tarafindan kanunların verdiği yetkiye istinaden ittihaz ve usulen tebliğ veya ilan olunan karar ve tedbirlerin tatbik ve icrasına muhalefet eden veya müşülat gösterenler veya riayet etmeyenler, mahallî mülkî amir tarafindan Kabahatler Kanununun 32 nci maddesi hükmü uyarınca cezalandırllır. Ancak, kamu düzenini ve güvenliğini veya kişilerin can ve mal emniyetini tehlikeye düşürecek toplumsal olayların baş göstermesi hâlinde vali tarafindan kamu düzenini sağlamak amacıyla alınan ve usulüne göre ilan olunan karar ve tedbirlere aykırı davrananlar, üç aydan bir yıla kadar hapis cezasıyla cezalandirllır."
} 
ciddi belirtilerin bulunduğu hâllerde on beş günü geçmemek üzere belli yerlerde veya saatlerde kişilerin dolaşmalarını, toplanmalarını (...) düzenleyebilir veya k1sitlayabilir. Ancak "Belli yerlerde veya saatlerde" ifadesi ilin tamamını kapsayacak şekilde yorumlanamaz. Zira "belli" ifadesi "tüm" veya "her" ifadesinden farklı olup bütün içinde sınırlı bir payı ifade etmektedir. Ayrıca düzenlenecek ya da kısıtlanacak olanın kişilerin dolaşması ve/veya toplanması olduğu belirtilmektedir. Dolaşma veya toplanma COVID-19 sebebiyle getirilen sokağa çıkma kısıtlamalarının yoksun kıldığı hareket tarzlarından yalnızca ikisini ifade etmektedir. Ayrıca "toplanma" ifadesi biraz daha net olmakla birlikte "dolaşma" ifadesine yüklenmesi gereken anlam da belirli değildir. Sonuç olarak İl İdaresi Kanunu'nun 11. maddesinin C fikrasında sokağa çıkma kısıtlamaları açıkça düzenlenmediği gibi, düzenlenen yetkilerin genel sokağa çıkma yasağı getirecek genişlikte yorumlanması da mümkün değildir. ${ }^{50} \mathrm{Bu}$ sonuç yukarıda ifade edilen; hürriyetlerin geniş, sınırlamaların ve yetkilerin dar yorumlanması, sınırlamaların örtülü olarak öngörülememesi ve kanunla getirilmeyen sınırlamaların idari işlemlerle getirilememesinin sonucudur. ${ }^{51}$

\section{Umumi Hıfzısıhha Kanunu}

İl İdaresi Kanunu dışında sokağa çıkma kısıtlamalarında dayanak gösterilen diğer düzenlemeler Umumi Hıfzısıhha Kanunu'nda bulunmaktadır. Bu çerçevede Kanun'un 27. ve 72. maddelerine dayanılmaktadır.

Umumi Hifzısıhha Kanunu'nun 27. maddesi uyarınca, "Umumi hifzissihha meclisleri mahallin sihhi ahvalini daima nazarl dikkat önünde bulundurarak şehir ve kasaba ve köyler sihhi vaziyetinin islahına ve mevcut mahzurların izalesine yarayan tedbirleri alırlar. Sari ve salgin hastallklar hakkinda istihbaratı tanzim, sari ve içtimai hastalıklardan korunmak çareleri ve sihhi hayatın faideleri hakkında halkı tenvir ve bir sari hastalık zuhurunda hastalı̆̆ın izalesi için alınan tedbirlerin ifasına muavenet eylerler."

\footnotetext{
${ }^{50}$ Gemalmaz ve Şirin de İl İdaresi Kanunu'nun 11. maddesinin C fikrasının bu haliyle genelgelere dayanak olmasının mümkün olmadığını belirtmektedir. Bkz Burak Gemalmaz, 'COVID-19 Döneminde Hak ve Özgürlükler' (MÜHF Talks \#6: Burak Gemalmaz \& Tolga Şirin, 15 Mayıs 2020) < https://www.youtube.com/watch?v=YnckRrr3eNY > Erişim Tarihi 20 Mayıs 2020; Tolga Şirin, 'COVID-19 Döneminde Hak ve Özgürlükler' (MÜHF Talks \#6: Burak Gemalmaz \& Tolga Şirin, 15 Mayıs 2020) < https://www.youtube.com/watch?v=YnckRrr3eNY > Erișim Tarihi 20 Mayıs 2020. Ayrıca bkz Șirin (n 13) 37 .

51 Ceza Muhakemesi Kanunu'nun gözaltıyı düzenleyen 91. maddesinde, “10/6/1949 tarihli ve 5442 sayll İl İdaresi Kanununa dayanılarak ilan edilen sokağa çıma yasağını ihlal etme", mülki amirlerce belirlenecek kolluk amirleri tarafindan yirmi dört saate kadar gözaltı kararı verilebilecek hallerden birisi olarak sayılmaktadır. İl İdaresi Kanunu'nda sokağa çıkma yasağının getirilmesine ilişkin açık bir hüküm yoktur. Söz konusu düzenlemenin “İl İdaresi Kanunu'nun 11. maddesinin C fıkrası uyarınca alınan karar ve tedbirlere aykırı hareket etme"yi farklı bir kategori altına alması beklenirdi. Tüm eleștirilere rağmen sokağa çıkma kısıtlamasını İl İdaresi Kanunu'nda açıkça düzenlemeyen kanun koyucunun Ceza Muhakemesi Kanunu'nda sokağa çıkma yasağından açıkça bahsetmesi de ilginçtir. İl İdaresi Kanunu'nun, mevcut haliyle sokağa çıkma yasağına dayanak olamayacağı savunulduğundan Ceza Muhakemesi Kanunu'ndaki hükmün de uygulama alanı bulmaması gerekir.
} 
Umumi Hıfzısıhha Kanunu'nun 72. maddesi uyarınca, "57 nci maddede zikredilen hastalıklardan biri zuhur ettiği veya zuhurundan şüphelenildiği takdirde aşağıda gösterilen tedbirler tatbik olunur:

1- Hasta olanların veya hasta olduğundan şüphe edilenlerin ve hastalığı neşrü tamim eylediği tetkikatı fenniye ile tebeyyün edenlerin fennen icap eden müddet zarfinda ve sihhat memurlarinca hanelerinde veya sihhi ve fenni şartları haiz mahallerde tecrit ve müşahede altına vaz' $\imath$.

2- Hastalara veya hastalığa maruz bulunanlara serum veya aşı tatbikı.

3- Eşhas, eşya, elbise, çamaşır ve binaların ve fennen intana maruz olduğu tebeyyün eden sair bilcümle mevaddin fenni tathiri.

4- Hastalık neşreden haşarat ve hayvanatın itlafi.

5- Memleket dahilinde seyahat eden eşhasin icap eden mahallerde muayenesi ve eşyalarının tathiri.

6- Hastalı̆̆ı sirayet ve intişarına sebebiyet veren glda maddelerinin sarf ve istihlakinin men'i.

7- Dahilinde sari ve salgin hastaliklardan biri zuhur eden umumi mahallerin tehlike zail oluncaya kadar set ve tahliyesi."

Umumi Hıfzısıhha Kanunu'nun 57. maddesi uyarınca, "Kolera, veba (Bübon veya zatürree şekli), lekeli humma, karahumma (hummayi tiroidi) daimi surette basil çıkaran mikrop hamilleri dahi - paratifoit humması veya her nevi gıda maddeleri tesemmümatı, çiçek, difteri (Kuşpalazı) - bütün tevkiatı dahi sari beyin humması (Iltihabı sahayai dimağii şevkii müstevli), uyku hastalı̆g (Iltihabı dimağii sari), dizanteri (Basilli ve amipli), lohusa humması (Hummai nifasl) ruam, kzzll, şarbon, felci tıfli (Iltihabı nuhai kuddamii sincabii haddı tifli), kızamı, cüzam (Miskin), hummai racia ve malta hummass hastaliklarindan biri zuhur eder veya bunlartn birinden şüphe edilir veyahut bu hastallklardan vefiyat vuku bulur veya mevtin bu hastalıklardan biri sebebiyle husule geldiğinden şüphe olunursa aşağıdaki maddelerde zikredilen kimseler vak'ayı haber vermeğe mecburdurlar. Kudurmuş veya kuduz şüpheli bir hayvan tarafindan isırlmalarl, kuduza müptela hastaların veya kuduzdan ölenlerin ihbarı da mecburidir."

Görüldüğü üzere, 57. maddede COVID-19 say1lmamaktadır. Üstelik maddede, sayılan hastalıklar dışında "ve diğer salgın hastalıklar" gibi bir ifade bulunmamaktadır. Anayasa Mahkemesi de Umumi Hifzısıhha Kanunu m. 57'de yer verilen hastalıkların sınırlı olarak sayıldığını kabul etmektedir. Nitekim zorunlu aşı uygulamasının anayasallığının sorgulandığı kararlarda Mahkeme, Umumi Hıfzısıhha Kanunu'nun 
57. maddesinde hastalıkların "tahdidi", bir diğer deyişle sınırlı olarak sayıldığını ifade etmektedir. ${ }^{52}$ Ancak belirtmek gerekir ki Kanun'un 64. maddesi,,${ }^{53} 57$. maddede sayılanlar dışındaki hastalıklar bakımından da kanunda belirtilen tüm tedbirlerin uygulanabileceğini belirtmektedir.

64. madde hükmüne dayanılarak COVID-19'un 57. madde kapsamında görülebileceği kabul edilse dahi 27. ve 72. maddelere dayanılarak sokağa çıkma kısitlamaları getirilmesi yine mümkün gözükmemektedir. Gerçekten de 72. maddede hastalar, hasta olduğundan şüphe edilenler ile hastalığı yayanların tecrit edilmesi, bunlara serum ve aşı uygulanması, hastalığ yayan hayvanların itlafi, hastalığa yol açan yahut hastalığı bulaştıran gıdalara ilişkin sınırlamalar getirilmesi, memleket dahilinde seyahat edenlerin muayenesi ve hastalk sebebiyle belirli yerlerin boşaltılmasından bahsedilmektedir. Maddede hastalık taşıyanların tecrit edilmesi ve bunlara tedavi uygulanmasının dışında kişilerin özgürlüğünden alıkonulması veya genel bir sokağa çıkma kısıtlaması öngörülmemektedir. ${ }^{54}$

Kanun'un 27. maddesinde ise Umumi Hifzısıhha Meclislerinin genel görevlerinden bahsedilmektedir. Bu bakımdan söz konusu madde görünüm açısından İl İdaresi Kanunu'nun 2018 değişiklikleri öncesindeki 11. maddesinin C fikrasına, değişiklikler sonrasındaki 11. maddesinin $\mathrm{C}$ fikrasının birinci bendine benzemektedir. Her iki hüküm de görev ve yetkilerden "genel olarak" bahsetmektedir. ${ }^{55}$ İl İdaresi Kanunu'nun söz konusu hükmüne dayanılarak getirilen sokağa çıkma kısıtlamaları ile ilgili öğreti ve Venedik Komisyonunun eleştirilerinin tamamının Umumi Hıfzısıhha Kanunu'nun 27. maddesine dayanılarak sokağa çıkma kısıtlaması getirilmesi bakımından da geçerli olduğu söylenebilir. Zira bu maddede de sokağa çıkma kısıtlamaları açıkça düzenlenmemiş, kısıtlamalar esnasında alınacak tedbirlerle ilgili hukuki çerçeve çizilmemiş, sınırlamalara ilişkin güvencelere yer verilmemiştir. Hatta bu kanunun salt dili sebebiyle belirlilik ve öngörülebilirlik kriterlerini karşılamadığı

\footnotetext{
$\overline{52}$ "Genelge kapsamında yer verilen așı türlerine bakıldığında 1593 sayılı Kanun'un 57. maddesinde tahdidi olarak sayılan hastalıklar için tatbiki öngörülenlerle sınırl bir düzenleme olmadı̆̆ anlaşılmakta, başvurucuya tatbikine hükmedilen HepB, DaBT, IPA, Hib ve KPA türündeki aşıların da 1593 sayılı Kanun'un 57. maddesinde tahdidi olarak sayılan hastalıkları tam olarak karşılamadığ , bu kapsamda 57. maddede zikredilen hastalıklardan birinin ortaya çıması veya ortaya çıkmasından şüphe edilmesi durumunda hastalara veya hastalı̆̆a maruz bulunanlara serum veya aşı uygulanması hususunu düzenleyen 72. madde hükmünün, başvuruya konu uygulamanın kanuni dayanağl olarak kabul edilmesinin mümkün olmadığı anlaşılmaktadır." Bkz Anayasa Mahkemesi, Bireysel Başvuru, 2013/1789, 11.11.2015, § 71. Aynı yönde: Anayasa Mahkemesi, Bireysel Başvuru, 2013/7246, 23/03/2016; Anayasa Mahkemesi, Bireysel Başvuru, 2014/4077, 29.06.2016; Anayasa Mahkemesi, Bireysel Başvuru, 2014/5629, 21.11.2017. Söz konusu kararlarla ilgili değerlendirme için bkz Korkut Kanadoğlu, 'Zorunlu Aşının Anayasallı̆̆ı' (Lexpera Blog, 20 Şubat 2020) < https://blog.lexpera.com.tr/ zorunlu-asinin-anayasalligi/ > Erişim Tarihi 20 Mayıs 2020.

53 Kanun’un 64. maddesi șu șekildedir: " 57 nci maddede zikredilenlerden bașka her hangi bir hastalık istilai șekil aldiğg veya böyle bir tehlike baş gösterdiği takdirde o hastalı̆̆ı veya her hangi bir hastalık şeklinin memleketin her tarafinda veya bir kısmında ihbarı mecburi olduğunu neşrü ilâna ve o hastalı̆̆a karşı bu kanunda mezkür tedabirin kaffesini veya bir kısmını tatbika Sihhat ve Içtimai Muavenet Vekaleti salahiyettardır."

54 Aynı yönde: Gemalmaz (n 50); Şirin (n 13) 38.

55 Şirin de Umumi Hıfzısıhha Kanunu'nun 27. maddesinin oldukça genel nitelikte olduğunu ve kullanılacak yetkiler bakımından hukuki belirlilik içermediğini ifade etmektedir. Bkz Şirin (n 13) 38.
} 
dahi söylenebilir. ${ }^{56}$ Sonuç olarak kanunun kalitesi, yetkilerin dar yorumlanması ve sınırlamaların açık şekilde öngörülmesi zorunluluğu başta olmak üzere yukarıda ele alınan hususlar 1şığında Umumi Hıfzısıhha Kanunu'nun ilgili hükümlerinin de 1982 Anayasası'nın 13. maddesinde öngörülen kanunilik ilkesinin gereklerini karşılamadığı söylenebilir.

\section{Sokağa Çıkma Kısıtlamasının Öngörüldü̆ğü Kanunlar}

Görüldügü üzere, mevcut anayasal ve kanuni düzenlemeler karşısında geniş çaplı sokağa çıkma kısıtlamalarının olağan dönemde getirilmesi mümkün değildir. Sokağa çıkma kısıtlamalarının açıkça düzenlendiği kanun ise 2935 sayılı Olağanüstü Hal Kanunu'dur. ${ }^{57} \mathrm{Bu}$ Kanun'da sokağa çıkma kısıtlamaları, şiddet hareketlerinde alınacak tedbirleri düzenleyen 11. maddede düzenlenmektedir. Söz konusu madde uyarınca,

"Bu Kanunun 3 üncü maddesinin birinci fikrasinın (b) bendi gereğince olağanüstü hal ilanında; genel güvenlik, asayiş ve kamu düzenini korumak, şiddet olaylarının yaygınlaşmasını önlemek amacıyla 9 uncu maddede öngörülen tedbirlere ek olarak aşağıldaki tedbirler de alınabilir: a) Sokağa çımayı sinırlamak veya yasaklamak, b) Belli yerlerde veya belli saatlerde kişilerin dolaşmalarını ve toplanmalarınt, araçların seyirlerini yasaklamak..." Maddenin devamında alınacak diğer tedbirler bentler halinde sayılmaktadır. Burada dikkat çekici olan, kanun koyucunun sokağa çıkma kısıtlamalarını; Kanun'un 3. maddesinin b bendi gereğince, yani Anayasa ile kurulan hür demokrasi düzenini veya temel hak ve hürriyetleri ortadan kaldırmaya yönelik yaygın şiddet hareketlerine ait ciddi belirtilerin ortaya çıkması veya şiddet olayları sebebiyle kamu düzeninin ciddi şekilde bozulması hallerinde ilan edilen olağanüstü hallerde uygulanacak bir tedbir olarak öngörmüş olmasıdır. Nitekim 11. maddede sokağa çıkma kısıtlamaları, 9. madde uyarınca alınabilecek tedbirlerin dışında, ek tedbirler arasında sayılmaktadır. 9. madde ise tabii afet ve tehlikeli salgın hastalıklar sebebiyle olağanüstü hâl ilan edilmesi durumunda alınacak tedbirleri düzenlemektedir. Özetle söylemek gerekirse, kanunda sokağa çıkma kısıtlamaları tabii afet ve tehlikeli salgın hastalıklar sebebiyle olağanüstü hâl ilan edilmesi halinde dahi uygulanacak bir tedbir olarak sayılmamış, bu hallerde alınması mümkün tedbirlere ek bir tedbir olarak, şiddet hareketleri sebebiyle ilan edilen olağanüstü

\footnotetext{
56 Eren'e göre COVID-19 sebebiyle uygulanan tedbirlerin dayanağı Umumi Hıfzısıhha Kanunu'nda bulunmakla birlikte Kanun'un dili sebebiyle ulaşılabilirlik ve anlaşılabilirlik sorunu bulunmaktadır. Bkz Abdurrahman Eren, 'Korona Virüs Yasaklarının Anayasaya Uygunluğu' (2020) < http://www.kanuniesasi.com/2020/04/16/korona virus-yasaklarininanayasaya-uygunlugu/ > Erişim Tarihi 15 Mayıs 2020.

57 Yürürlükten kaldırılmadan önce 1402 sayılı Sıkıyönetim Kanunu'nun 3. maddesinde de sıkıyönetim komutanının sokağa çıkma kısıtlamaları getirebileceği düzenlenmekteydi.
} 
hâllere özgülenmiştir. ${ }^{58} \mathrm{Bu}$ durumda ortaya çıkan sonuç şudur: Salgın hastalıklar sebebiyle olağanüstü hâl ilan edilse dahi yürütme organına genel bir sokağa çıkma kısıtlaması getirme yetkisi tanımayan ve bu tedbiri şiddet hareketleri sebebiyle ilan edilen olağanüstü hallerle sınırlayan bir hukuk düzeninde İl İdaresi Kanunu ve Umumi Hıfzısıhha Kanunu'nda yer alan, görev ve yetkilere ilişkin genel düzenlemelere dayanılarak sokağa çıkma kısıtlamaları getirilmesi mümkün değildir. ${ }^{59}$ Olağanüstü Hal Kanunu'ndaki bu düzenleme olmasaydı dahi üst başlıklarda yapılan açıklamalarla aynı sonuca varılması gerekirdi. Ancak Olağanüstü Hâl Kanunu'ndaki bu düzenleme, ulaşılan sonucu daha da desteklemektedir.

Tüm bu söylenenlere ek olarak bir hususa daha dikkat çekilmesinde yarar bulunmaktadır. Görüldüğü üzere Olağanüstü Hal Kanunu sokağa çıkmayı sınırlamak veya yasaklamak ile belli yerlerde veya belli saatlerde kişilerin dolaşmalarını ve toplanmalarını, yasaklamayı ayrı tedbirler olarak saymaktadır. Yukarıda belirtildiği üzere, COVID-19 sebebiyle getirilen sokağa çıkma kısıtlamalarının dayanağı olarak gösterilen İl İdaresi Kanunu'nun 11. maddesinin C fikrasında belli yerlerde veya saatlerde kişilerin dolaşmalarının, toplanmalarının düzenlenebileceği veya kısıtlanabileceği belirtilmektedir. Belli yerlerde kişilerin dolaşmaları veya toplanmalarının kısıtlanabilmesinin sokağa çıkma kısıtlamasını içerecek şekilde yorumlanması mümkün olsaydı, Olağanüstü Hal Kanunu’nda sokağa çıkma kısıtlamaları ile belli yerlerde veya belli saatlerde kişilerin dolaşmaları ve toplanmalarının ayrı ayrı düzenlenmesi gerekmezdi. Olağanüstü hâlde dahi sokağa çıkma kısıtlamalarını belli yerlerde veya belli saatlerde kişilerin dolaşmalarını ve toplanmalarını yasaklama içinde saymayıp ayrıca düzenleme gereği duyan bir hukuk düzeninde olağan dönemde uygulanan bir mevzuatta yer alan hemen hemen aynı düzenlemenin sokağa çıkma kısıtlamalarını içerdiğini savunmak mümkün değildir. ${ }^{60}$ Yukarıda ulaşılan sonuca benzer şekilde, Olağanüstü Hal Kanunu'ndaki bu düzenleme olmasaydı dahi üst başlıklarda yapılan açıklamalarla aynı sonuca varılması gerekirdi. Ancak Olağanüstü Hâl Kanunu’ndaki bu düzenleme, ulaşılan sonucu daha da desteklemektedir.

\footnotetext{
Kanun'un 2. maddesi uyarınca, “Bu Kanun; olağanüstü hal ilanına tabii afet, tehlikeli salgın hastalıklar veya ağır ekonomik bunalım hallerinde ilan edilen olağanüstü hallerde vatandaşlar için getirilecek para, mal ve çalışma yükümlülükleri ile olağanüstü hallerin her türü için ayrı ayr geçerli olmak üzere, temel hak ve hürriyetlerin nasıl sınırlanacağl veya nasıl durdurulacağına, halin gerektirdiği tedbirlerin nasll ve ne suretle alınacağına, kamu hizmeti görevlilerine ne gibi yetkiler verileceğine, görevlilerin durumlarında ne gibi değişiklikler yapılacağına ve olağanüstü yönetim usullerine iliş̧kin hükümleri kapsar."

59 Benzer sorunun COVID-19 sebebiyle getirilen diğer kısıtlamalar bakımından da geçerli olduğu söylenebilir. Nitekim belirli yerleşim yerlerine giriş ve çıkışların sınırlandırılması, resmi ve özel eğitim ve öğretim kurumlarında öğrenime ara verilmesi, lokanta, sinema, tiyatro gibi yerlerin kapatılması gibi tedbirler tabii afet ve tehlikeli salgın hastalıklar sebebiyle olağanüstü hâl ilanında alınabilecek tedbirler olarak Kanun'un 9. maddesinde sayılmaktadır. Dolayısıyla kanunilik ilkesi bakımından çalışmada tespit edilen sorunların, COVID-19'la mücadele çerçevesinde alınan birçok tedbirle ilgili var olduğu söylenebilir. Olağanüstü Hal Kanunu'nun tanıdığı yetkilerle ilgili ayrıntılı bilgi için bkz Selin Esen, Karşılaş̧ırmalı Hukukta ve Türkiye'de Olağanüstü Hal Rejimi (Adalet 2008) 187-207.

${ }^{60}$ Benzer yönde: Eren (n 56).
} 


\section{Sonuç}

Olağan dönemde temel hak ve özgürlüklere müdahale edildiğinde 1982 Anayasası'nın 13. maddesinde belirtilen 7 koşula uyulması gerekmektedir. Ancak COVID-19 sebebiyle getirilen sokağa çıkma kısıtlamaları Anayasa'da belirtilen sebeplerle getirilmiş olsa dahi kanunilik ilkesinin gereklerine uymamaktadır. Kanunilik ilkesine aykırı olan müdahalelerin de 13. maddede belirtilen diğer koşullara uygunluğunu incelemeye gerek yoktur. Kanunilik ilkesine uyulmamış olması söz konusu müdahaleleri başlı başına anayasaya aykırı hale getirmektedir. Ancak kanunilik ilkesine uyulmuş olsaydı dahi COVID-19 sebebiyle uygulanan sokağa çıkma kısıtlamaların tamamının Anayasa’ya uygun hale geleceğini söylemek pek de gerçekçi gözükmemektedir. Özellikle belli yaş gruplarında bulunan kişilerle kronik hastalığı bulunanların sokağa çıkmasının günlerce yasaklanmasının hakkın özü ve ölçülülük ilkesine uygunluğu oldukça şüphelidir. ${ }^{61}$

Olağanüstü hâl ilanının ardından uygulanacak sokağa çıkma kısıtlaması ile ilgili kuralların, başvuru yollarının ve güvencelerin daha belirgin olmasına karşıllık, İl İdaresi Kanunu ile Umumi Hıfzısıhha Kanunu'na dayanılarak olağan dönemde uygulanan sokağa çıkma kısıtlamalarına ilişkin kuralların, başvuru yollarının ve kısıtlama koşullarının belirli ve açık olmaması oldukça ilginçtir. ${ }^{62}$ İki ayı aşkın zamandır uygulanan kısıtlamaların artık öngörülebilir olması ve sonraki süreçte de uygulanacağının varsayılması da kanunilik ilkesinin gereklerini yerine getirmemektedir. Anayasa Mahkemesinin isabetle belirttiği üzere, “(...) temel bir hak ve özgürlüğe yapılan müdahalenin süreklilik kazanarak ulaşılabilir ve öngörülebilir hale gelmesi, müdahalenin dayanağı olan kamu gücü işlemini bir "kanun" haline getirmez. Aksi bir düşüncenin kabulü, ulaşılabilir ve öngörülebilir bir kamu gücü işleminden veya eyleminden kaynaklanan hak ihlallerinin "kanuni" dayanaklarının olduğunun kabul edilmesi anlamına gelecektir." ${ }^{63}$ Dolayısıyla sokağa çıkma kısıtlamaları öngören genelgeler, çalışmanın başında alıntılanan anıdaki genelgeden pek de farklı durumda değildir.

Sokağa çıkma kısıtlamaları ve genelgelerle getirilen diğer kısıtlamalara uymayanlara idari para cezaları başta olmak üzere çeşitli yaptırımlar uygulanmaktadır. Bu çerçevede bazı idari para cezaları İl İdaresi Kanunu'nun yollamasıyla Kabahatler Kanunu'na dayanılarak, bazıları ise doğrudan Umumi Hıfzısıhha Kanunu'ndaki hükümlere dayanılarak kesilmektedir. Ancak kolluğun hangi kritere göre ayrım yaptığı anlaşılamamaktadır. Kişilerin hak ve hürriyetleri kanuni olmayan müdahalelerle sınırlandırıldığı gibi, sınırlamaları ihlal etmeleri halinde kişiler hangi kanuna göre yaptırıma uğrayacaklarını da kestirememektedir. Söz konusu idari para cezaları ile diğer işlemler yargı önüne getirildiğinde bu işlemlerin iptal edilmesi işten bile

\footnotetext{
1 Aynı yönde: Şirin (n 50).

62 Benzer yönde: European Commission For Democracy Through Law (Venice Commission) (n 7) § 78-83.

63 Anayasa Mahkemesi, Bireysel Başvuru, 2014/256, 25.06.2014, § 96.
} 
değildir. Uyuşmazlıkların bireysel başvuru yoluyla Anayasa Mahkemesinin önüne gelmesi halinde de Mahkeme muhtemelen kanunilik ilkesine aykırılık sebebiyle ihlal kararları verecektir. Söz konusu sorunların ve çalışmanın tamamında değinilen hukuka aykırılıkların giderilebilmesi için kapsamlı kanunların yapılması gerekmektedir. Bu çerçevede ilk olarak, salgın hastalıklarda -sokağa çıkma kısıtlamaları dahil- temel hak ve özgürlüklerin hangi önlemlerle, hangi sürelerle sınırlanabileceğine ilişkin düzenlemelerin getirilmesi kaçınılmaz gözükmektedir. ${ }^{64}$ Aksi takdirde mevcut, "olağan" mevzuat sokağa çıkma kısıtlamaları getirilmesi için yeterli olmadığından olağanüstü hâl ilan edilmesi gerekmektedir. ${ }^{65}$ Ancak olağanüstü hâl ilan edilse dahi Olağanüstü Hal Kanunu sokağa çıkma kısıtlamalarını şiddet sebebiyle ilan edilen olağanüstü haller için öngörmektedir. Bu durumda sokağa çıkma kısıtlamalarının salgın hastalıklar sebebiyle de getirilebileceğine ilişkin Olağanüstü Hal Kanunu'nda değişiklik yapılması veya olağanüstü hâl ilanının ardından çıkarılacak olağanüstü hâl Cumhurbaşkanlığı kararnameleri ile sokağa çıkma kısıtlamalarının getirilmesi gerekmektedir. ${ }^{66}$ Ancak bu önerilerin gerçekleştirilmesi tedbirlerin yalnızca kanuniliğini sağlayabilir. Tüm kanuni düzenlemeler yapılsa dahi getirilecek sınırlamaların ölçülülüğü ayrı bir tartışma konusudur.

Valilerin ve Umumi Hıfzıssıhha Meclislerinin genel olarak görevlerini belirten maddelere dayanılarak, sınırlama tipinin adı dahi anılmaksızın temel hak ve özgürlüklerin durumun gereklerine göre sınırlandırılabileceğini savunmak hukukumuzdaki birçok kanunun da gereksiz olduğunu kabul etmek anlamına gelmektedir. Örneğin polis ve savcıların emniyeti, kamu düzenini ve yargılamaların adil olmasını sağlayacaklarına ilişkin kanuni bir düzenleme olsun. Bu durumda polisin zor ve silah kullanmasına ilişkin Polis Vazife ve Salâhiyet Kanunu, m. 16 hükümlerinin veya gözaltı koşullarını düzenleyen Ceza Muhakemesi Kanunu, m. 91 hükümlerinin gereksiz olduğu ve bu konuların genelgelerle düzenlenebileceği söylenebilir mi? Bir hukuk devletinde bu soruya olumlu cevap vermek mümkün gözükmemektedir. Hâkim kararı olmaksızın bir kişinin en fazla 48 saat hürriyetinden yoksun bırakılabileceğini belirten bir Anayasa'nın (m. 19) yürütme organının kanunlarda koşulları belirtilmemiş şekilde kişileri günlerce evde tutabileceğine cevaz verdiğini kabul etmek ne kadar doğrudur? Okuyucunun düşünmesi gerekir: 50 gün ev hapsi mi hürriyete daha çok dokunur, 48 saat gözaltında kalmak mı?

\footnotetext{
${ }^{4}$ Şirin, olağan dönem içinde kapsamlı bir kanunla sürecin yürütülmesinin yerinde olacağını belirtmektedir. Bkz Şirin (n 50).

65 Aynı yönde: Ardıçoğlu (n 41); Karagöz (n 41) 632. Ayrıca bkz Kemal Gözler, 'Korona Virüs Salgınıyla Mücadele İçin Alınan Tedbirler Hukuka Uygun mu? (2)' (2020) < www.anayasa.gen.tr/korona-2.htm > Erişim Tarihi 20 Temmuz 2020; Volkan Aslan, 'COVID-19 Sebebiyle Uygulanan Sokağa Çıkma Kısıtlamaları Hukuka Uygun mu?' (Liberal Perspektif Yorum, Ağustos 2020) < https://oad.org.tr/Content/BlogResimleri/pdf/20208131 41544247\%C3\%96AD $\% 20 \% 20$ Yorum $\% 2016 \% 20 \% 20$ COVID $19 \% 20$ Sebebiyle $\% 20$ Uygulanan $\% 20$ Soka $\% C 4 \% 9 F a \% 20 \% \mathrm{C} 3 \% 87 \% \mathrm{C} 4 \% \mathrm{~B} 1 \mathrm{kma} \% 20$ K\%C4\%B1s\%C4\%B1tlamalar\%C4\%B1\%20Hukuka\%20Uygun\%20mu \%20-\%20Volkan\%20Aslan\%20(08-20).pdf > Erișim Tarihi 14 Ağustos 2020

66 Olağanüstü hâllerde dahi temel hak ve özgürlüklerle ilgili sınırlamaların Cumhurbaşkanlığı kararnameleri ile yapılmamas gerektiği yolunda bir görüş de bulunmaktadır. Olağanüstü hâl Cumhurbaşkanlığı kararnameleri ile ilgili ayrıntılı bilgi için bkz Volkan Aslan, Karşılaştırmalı Anayasa Hukukunda ve Türkiye'de Devlet Başkanının Kararname Yetkisi (On İki Levha 2020) 309-320.
} 
Hakem Değerlendirmesi: Dış bağımsız.

Çıkar Çatışması: Yazar çıkar çatışması bildirmemiştir.

Finansal Destek: Yazar bu çalışma için finansal destek almadığını beyan etmiştir.

Teşekkür: Çalışmanın yayımlanması sürecinde göstermiş olduğu ilgi ve verdiği emek için İ̈HHF İdare Hukuku Ana Bilim Dalı’ndan Arş. Gör. Mustafa Ahioğlu'na teşekkür ederim. Yayımlanmadan önce metni gözden geçiren ve değerli görüşlerini paylaşan İzmir Demokrasi Üniversitesi Hukuk Fakültesinden Arş. Gör. Gülçin Demircan'a ayrıca teşekkür ederim

Peer-review: Externally peer-reviewed.

Conflict of Interest: The author has no conflict of interest to declare.

Grant Support: The author declared that this study has received no financial support.

Acknowledgement: I would like to thank Ress. Asst. Mustafa Ahioğlu from the IUHF Administrative Law Department for his interest and effort in the publication of the study. I would also like to thank Gülçin Demircan, from Izmir Democracy University Faculty of Law, who reviewed the text before it was published and shared her valuable opinions. 


\section{Bibliyografya/Bibliography}

Anayurt Ö, Anayasa Hukuku Genel Kısım (Temel İlkeler, Kavram ve Kurumlar) (2. Bası, Seçkin 2019).

Ardıçoğlu A, 'Hukuka Uygun Olmayan Sokağa Çıkma Yasağı Hukuka Aykırı Mıdır?' (Birikim Dergisi, 27 Kasim 2015) > https:/www.birikimdergisi.com/guncel/7331/hukuka-uygunolmayan-sokaga-cikma-yasagi-hukuka-aykiri-midir > Erişim Tarihi 25 Mayıs 2020.

Arslan Z, 'Temel Hak ve Özgürlüklerin Sınırlanması: Anayasa'nın 13. Maddesi Üzerine Bazı Düşünceler' (2002) 19 Anayasa Yargıs1 Dergisi 216-231.

Aslan, V, 'COVID-19 Sebebiyle Uygulanan Sokağa Çıkma Kısıtlamaları Hukuka Uygun mu?' (Liberal Perspektif Yorum, Ağustos 2020) < https://oad.org.tr/Content/BlogResimleri/ $\mathrm{pdf} / 2020813141544247 \% \mathrm{C} 3 \% 96$ AD $\% 20 \% 20$ Yorum $\% 2016 \% 20 \% 20$ COVID $19 \% 20$ Sebebiyle\%20Uygulanan\%20 Soka \%C 4\% 9Fa\%20\%C3\% $87 \%$ C 4\%B 1 kma $\% 20$ K\%C4\%B1s\%C4\%B1tlamalar\%C4\%B1\%20Hukuka\%20Uygun\%20mu_\%20-\%20 Volkan\%20Aslan\%20(08-20).pdf > Erişim Tarihi 14 Ağustos 2020.

Aslan V, Karşılaştırmalı Anayasa Hukukunda ve Türkiye'de Devlet Başkanının Kararname Yetkisi (On İki Levha 2020).

Aslan V, 'Turkey's Struggle Against COVID-19 and the New Reign-by-Administrative-Act' (IACL-IADC Blog 2020) < https://blog-iacl-aidc.org/2020-posts/2020/7/16/turkeys-struggleagainst-covid-19-and-the-new-reign-by-administrative-act > Erişim Tarihi 17 Temmuz 2020.

Bozkurt T, ‘Anayasa Mahkemesi'nin 4857 Sayılı İş Kanunu'ndaki Engelli ve Eski Hükümlü Çalıştırma Zorunluluğunun Anayasa'ya Uygun Olduğuna Dair Verdiği Karar Üzerine Düşünceler' (2009) 2 Ankara Barosu Dergisi 98-105.

Bulut N, '4709 sayılı Kanunla Yapılan Anayasa Değişikliği Çerçevesinde Hak ve Özgürlüklerin Sınırlanması Rejiminin Birey Devlet İlişkisi Açısından Değerlendirilmesi' (2001) 5(1-4) Atatürk Üniversitesi Erzincan Hukuk Fakültesi Dergisi 37-64.

Cin Karagöz E, 'Özel Güvenlik Bölgesi ve Sokağa Çıkma Yasağı İlanının Hukuki Niteliği ve Uygulamadan Kaynaklı Sorunlar' (2016) 20(2) Gazi Üniversitesi Hukuk Fakültesi Dergisi 625-645.

Erem F, Bir Ceza Avukatının Anıları, (14. Bası, Lykeion 2020).

Eren A, Anayasa Hukuku Ders Notlarl (Genel Esaslar-Türk Anayasa Hukuku) (On İki Levha 2018).

Eren A, 'Korona Virüs Yasaklarının Anayasaya Uygunluğu' $(2020)<\mathrm{http}: / / w w w . k a n u n i e s a s i$. com/2020/04/16/korona virus-yasaklarinin-anayasaya-uygunlugu/ > Erişim Tarihi 15 Mayss 2020.

Eren A, Özgürlüklerin Sinırlandırılmasında Demokratik Toplum Düzeninin Gerekleri (Beta 2004).

Esen S, Anayasa Hukuku Açısından Dolaşım Özgürlüğ̈̈ (Yetkin 2014).

Esen S, Karşılaştırmalı Hukukta ve Türkiye'de Olağanüstü Hal Rejimi (Adalet 2008).

European Commission For Democracy Through Law (Venice Commission), 'Turkey Opinion On The Legal Framework Governing Curfews', Adopted by the Venice Commission at its 107th Plenary Session (Venice, 10-11 June 2016) < https://www.venice.coe.int/webforms/documents/ default.aspx?pdffile=CDL-AD(2016)010-e > Erişim Tarihi 20 Mayıs 2020.

Fendoğlu HT, '2001 Anayasa Değişikliği Bağlamında Temel Hak Ve Özgürlüklerin Sınırlanması (Ay. Md.13.)' (2002) 19 Anayasa Yarg1s1 Dergisi 178-214.

Gemalmaz B, 'COVID-19 Döneminde Hak ve Özgürlükler' (MÜHF Talks \#6: Burak Gemalmaz \& Tolga Şirin, 15 Mayıs 2020) < https://www.youtube.com/watch?v=YnckRrr3e NY > Erişim Tarihi 20 Mayis 2020. 
Gözler K, 'Anayasa Değişikliğinin Temel Hak ve Hürriyetlerin Sınırlandırılması Bakımından Getirdikleri ve Götürdükleri (Anayasanın 13'üncü Maddesinin Yeni Şekli Hakkında Bir İnceleme)', (2001) 4 Ankara Barosu Dergisi 53-67.

Gözler K, Anayasa Hukukunun Genel Teorisi - Cilt I/Cilt II (Ekin 2011).

Gözler K, ‘Korona Virüs Salgınıyla Mücadele İçin Alınan Tedbirler Hukuka Uygun mu? (2)' (2020) $<$ www.anayasa.gen.tr/korona-2.htm>, Erişim Tarihi 20 Temmuz 2020.

Gözler K, ‘3 Ekim 2001 Tarihli Anayasa Değişikliği: Bir Abesle İştigal Örneği’ (2002) 19 Anayasa Yarg1s1 Dergisi 326-354.

Gözler K, İnsan Hakları Hukuku (Ekin 2017).

Gözler K, Türk Anayasa Hukuku (3. Bas1, Ekin 2019).

Göztepe E, 'Ein Paradigmenwechsel für den Sicherheitsstaat: Die Praxis des Ausnahmezustandes im Südosten der Türkei' iç Matthias Lemke (ed), Ausnahmezustand: Theoriegeschichte Anwendungen - Perspektiven (Springer VS 2017). $<$ https://mevzuat.tbmm.gov.tr/mevzuat/faces/ kanunmaddeleri?pkanunlarno=41587\&pkanun numarasi=5442 > Erişim tarihi 18 Mayıs 2020.

İnceoğlu S, ‘Hak ve Özgürlükleri Sınırlama ve Güvence Rejimi’ iç Sibel İnceoğlu (ed), İnsan Haklarl Avrupa Sözleşmesi ve Anayasa: Anayasa Mahkemesine Bireysel Başvuru Kapsamında Bir Inceleme (2. Bas1, Beta 2013).

Kanadoğlu K, 'Zorunlu Aşının Anayasallığı' (Lexpera Blog, 20 Şubat 2020) < https://blog.lexpera. com.tr/zorunlu-asinin-anayasalligi/ > Erişim Tarihi 20 Mayıs 2020.

Oder BE, Anayasa Yargısında Yorum Yöntemleri: Hukuksal Yöntembilime Dayalı Karşılaştırmalı Bir Araştırma (Beta 2010).

Sağlam F, '2001 Yılı Anayasa Değişikliğinin Yaratabileceği Bazı Sorunlar ve Bunların Çözüm Olanakları' (2002) 19 Anayasa Yarg1s1 Dergisi 288-310.

Sağlam F, Temel Hakların Sinırlanması ve Özü (AÜSBF 1982).

Sağlam M, 'Ekim 2001 Tarihinde Yapılan Anayasa Değişiklikleri Sonrasında, Düzenlendikleri Maddede Hiçbir Sınırlama Nedenine Yer Verilmemiş Olan Temel Hak ve Özgürlüklerin Sınırı Sorunu' (2002) 19 Anayasa Yargisı Dergisi 233-266.

Şirin T, 'COVID-19 Döneminde Hak ve Özgürlükler' (MÜHF Talks \#6: Burak Gemalmaz \& Tolga Şirin, 15 Mayıs 2020) < https://www.youtube.com/watch?v=YnckRrr3eNY > Erişim Tarihi 20 Mayıs 2020.

Şirin T, 'Eine Ausgangssperre Ohne Ausnahmezustand?' (2015) 4(7) Anayasa Hukuku Dergisi 275-288.

Şirin T, Özgürlük ve Güvenlik Hakkı: Anayasa Mahkemesine Bireysel Başvuru El Kitapları Serisi-1 (2. Bas1, Avrupa Konseyi 2019).

Şirin T, 'Tehlikeli Salgın Hastalıklarla Hukuksal Mücadeleye Anayasal Bir Giriş', (2020) $<$ https://www.academia.edu/42611036/TEHL\%C4\%B0KEL\%C4\%B0_SALGIN_ HASTALIKLARLA_HUKUKSAL_M\%C3\%9CCADELEYE_ANAYASAL_B\%C4\%B0R_G \%C4\%B0R\%C4\%B0\%C5\%9E > Erişim Tarihi 19 Mayıs 2020.

Tanör B ve Yüzbaşığlu N, 1982 Anayasasına Göre Türk Anayasa Hukuku (19. Bas1, Beta 2019).

\section{Kararlar}

Anayasa Mahkemesi, 2016/205, 24.07.2019.

Anayasa Mahkemesi, 2017/24, 14.06.2017.

Anayasa Mahkemesi, 2016/37, 14.07.2016.

Anayasa Mahkemesi, 2015/96, 10.02.2016. 
Anayasa Mahkemesi, 2014/87, 08.12.2015.

Anayasa Mahkemesi, 2014/176, 27.05.2015.

Anayasa Mahkemesi, 2014/149, 02.10.2014.

Anayasa Mahkemesi, 2011/150, 14.02.2013.

Anayasa Mahkemesi, 2012/35, 27.12.2012.

Anayasa Mahkemesi, 2010/83, 01.11.2012.

Anayasa Mahkemesi, 2006/142, 24.09.2008.

Anayasa Mahkemesi, 2008/66, 22.07.2008.

Anayasa Mahkemesi, 2006/101, 19.06.2008.

Anayasa Mahkemesi, 2007/4, 18.10.2007.

Anayasa Mahkemesi, 2000/82, 26.11.2002.

Anayasa Mahkemesi, 2001/5, 28.03.2002.

Anayasa Mahkemesi, 2000/48, 20.03.2002.

Anayasa Mahkemesi, Bireysel Başvuru, 2017/32754, 10.03.2020.

Anayasa Mahkemesi, Bireysel Başvuru, 2016/7628, 27.02.2020.

Anayasa Mahkemesi, Bireysel Başvuru, 2015/3324, 26.02.2020.

Anayasa Mahkemesi, Bireysel Başvuru, 2017/4483, 13.02.2020.

Anayasa Mahkemesi, Bireysel Başvuru, 2016/8080, 26.12.2019.

Anayasa Mahkemesi, Bireysel Başvuru, 2017/21973, 11.12.2019.

Anayasa Mahkemesi, Bireysel Başvuru, 2017/16005, 11.12.2019.

Anayasa Mahkemesi, Bireysel Başvuru, 2016/67737, 19.11.2019.

Anayasa Mahkemesi, Bireysel Başvuru, 2016/15421, 12.11.2019.

Anayasa Mahkemesi, Bireysel Başvuru, 2014/16877, 22.03.2018.

Anayasa Mahkemesi, Bireysel Başvuru, 2014/2889, 25.01.2018.

Anayasa Mahkemesi, Bireysel Başvuru, 2014/5629, 21.11.2017.

Anayasa Mahkemesi, Bireysel Başvuru, 2016/22169, 20.06.2017.

Anayasa Mahkemesi, Bireysel Başvuru, 2014/18849, 11.01.2017.

Anayasa Mahkemesi, Bireysel Başvuru, 2014/4077, 29.06.2016.

Anayasa Mahkemesi, Bireysel Başvuru, 2013/7246, 23/03/2016.

Anayasa Mahkemesi, Bireysel Başvuru, 2013/7666, 10.12.2015.

Anayasa Mahkemesi, Bireysel Başvuru, 2013/1789, 11.11.2015.

Anayasa Mahkemesi, Bireysel Başvuru, 2014/6193, 15.10.2015.

Anayasa Mahkemesi, Bireysel Başvuru, 2013/6693, 16.04.2015.

Anayasa Mahkemesi, Bireysel Başvuru, 2014/256, 25.06.2014.

Anayasa Mahkemesi, Bireysel Başvuru, 2014/4705, 29.05.2014.

Anayasa Mahkemesi, Bireysel Başvuru, 2013/2187, 19.12.2013. 
